\title{
Triphenylene-Imidazolium Salts and their NHC Metal Complexes, Materials with Segregated Multicolumnar Mesophases.
}

\author{
Ana B. Miguel-Coello, ${ }^{1}$ Manuel Bardají, ${ }^{1, *}$ Silverio Coco, ${ }^{1, *}$ Bertrand Donnio, ${ }^{2, *}$ Benoît Heinrich, ${ }^{2}$ and Pablo Espinet ${ }^{1, *}$ \\ ${ }^{1}$ IU CINQUIMA/Química Inorgánica, Facultad de Ciencias, Universidad de Valladolid, E-47071 Valladolid, Spain. \\ ${ }^{2}$ Institut de Physique et Chimie des Matériaux de Strasbourg (IPCMS), UMR 7504 (CNRS-Université de Strasbourg), 23 rue \\ du Loess, BP 43, 67034 Strasbourg Cedex 2, France. \\ *Authors to whom correspondence should be addressed.
}

Supporting Information Placeholder

\begin{abstract}
Two imidazolium salts containing one or two pentadodecyloxytriphenylene units linked through a hexyloxy chain and $\mathrm{Br}^{-},\left[\mathrm{AuBr}_{\mathrm{m}} \mathrm{Cl}_{4-\mathrm{m}}\right]^{-}$or $\left[\mathrm{PtBr}_{\mathrm{m}} \mathrm{Cl}_{4-\mathrm{m}}\right]^{2-}$ as counter-ion have been prepared. Reaction of the imidazolium bromides with $\mathrm{M}_{2} \mathrm{O}(\mathrm{M}=$ $\mathrm{Cu}, \mathrm{Ag})$, or carbene transmetalation from the silver product, leads to $\mathrm{N}$-heterocyclic carbene complexes $[\mathrm{MX}(\mathrm{NHC})](\mathrm{M}=\mathrm{Cu}, \mathrm{X}=$ $\mathrm{Br} ; \mathrm{M}=\mathrm{Au}, \mathrm{X}=\mathrm{Cl}, \mathrm{C} \equiv \mathrm{CPh}$,,$\left[\mathrm{Ag}(\mathrm{NHC})_{2}\right]\left[\mathrm{AgBr}_{2}\right]$, and $\left[\mathrm{PtCl}_{2}\left(\mathrm{NHC}_{2}\right]\right.$, with $\mathrm{NHC}$ bearing one or two triphenylene fragments. Except for the gold derivatives and one $\mathrm{Cu}$ complex, the rest of them behave as liquid crystals organized in columnar mesophases (rectangular $\mathrm{c} 2 \mathrm{~mm}$ or $\mathrm{p} 2 \mathrm{mg}$ or hexagonal $\mathrm{p} 6 \mathrm{~mm}$ symmetries) with melting points in the range 30 to $60{ }^{\circ} \mathrm{C}$ and clearing points in the range $57-112^{\circ} \mathrm{C}$. The mesophase structures were determined by small-angle X-ray scattering. Structural studies and models point out to nanosegregation of triphenylene columns and imidazolium/metal carbene moieties, separated by alkoxy chains, leading to multicolumnar systems. The compounds display emission spectra related to the triphenylene core in solution, in the mesophase, in the isotropic liquid, and in the solid state.
\end{abstract}

Keywords: metallomesogens, columnar liquid crystals, triphenylene, carbene, imidazolium, luminescence.

\section{INTRODUCTION}

Self-assembly of relatively simple molecules into higher-order systems is a useful strategy for the rational development of new functional materials with desired properties. Discotic liquid crystals, self-assembling disc-like molecules into columnar mesophases, are an interesting example. They present unique electronic and optoelectronic properties associated to their columnar structure, which makes them suitable for potential applications such as conductive devices, ${ }^{1}$ field-effect transistors, or photovoltaic solar cells. ${ }^{2-8}$ They are already commercially applied as birefringent films used to improve the viewing angle of liquid crystal displays." ${ }^{9,10}$ Triphenylenebased discotic mesogens and their columnar mesophases have been the subject of numerous systematic studies on structureproperties relationships, ${ }^{11}$ due their high thermal and chemical stability, and their rich and highly developed chemistry.

The properties of columnar mesophases are frequently related to their degree of structural organization. Therefore, understanding their dynamics and phase behavior at the molecular scale is fundamental for improved rational design. In this regard, molecules containing moieties different in nature and prone to self-assemble individually in separate domains may favor the emergence of new supramolecular organizations with new structures and new properties. ${ }^{12}$ For example, the combination of rod and disc fragments within the same molecule has been used to achieve unconventional mesophases with well-ordered morphologies at the nanometric scale. ${ }^{13}$ The microsegregation of dispersed single component columns different in nature can provide heterojunction columnar structures exhibiting useful properties such as ambipolar charge transport properties, ${ }^{14-18}$ or efficient photocurrent generation. $^{19,20}$

The strong stacking tendency of triphenylene provides an efficient structure for one-dimensional charge mobility. ${ }^{21}$ The functionalization of the triphenylene core with long chains containing different functional groups, ${ }^{22}$ including organometallics or coordination metal complexes, ${ }^{23-29}$ offers many opportunities to modulate the properties of the system while conserving the tendency to columnar organization. We have already reported mesomorphic organometallic complexes containing triphenylene moieties where $\pi$-stacking of the triphenylene discs in columns and aggregation of the metallic moieties into segregated columnar zones coexist in a wellordered manner in the mesophase. ${ }^{30}$ With metallic fragments able to produce Pt $\cdots$ Pt interactions, highly stabilized phosphorescent mesophases based on these interactions were obtained. ${ }^{29,31,32,33}$

The successful design of metal-containing mesomorphic triphenylene complexes reported in our initial studies prompted us to extend this investigation further to imidazolium triphenylene halides, their gold(I) and platinum(II) salts, and some N-heterocyclic carbene (NHC) complexes of $\mathrm{Cu}^{\mathrm{I}}, \mathrm{Ag}^{\mathrm{I}}$, 
$\mathrm{Au}^{\mathrm{I}}$ and $\mathrm{Pt}^{\mathrm{II}}$. Imidazolium salts are precursors of $\mathrm{N}$ heterocyclic carbene metal complexes extensively studied not only in organometallic chemistry and catalysis, but also in biological applications. ${ }^{34,35} \mathrm{~N}$-Substituted imidazolium salts display a variety of mesophases and properties depending on the N-substituents and the counteranion. ${ }^{36}$ Our purpose in this work is to use imidazolium-metal moieties as modifiers of the promesogenic triphenylene groups that can bring with them metal fragments, and see whether this leads to hybrid organic/inorganic multi-columnar mesophases. More specifically we want to know whether columnar piling is induced in the imidazole-metal moieties, which themselves are not promesogenic. This is the case for organic triphenylene- disubstituted imidazolium salts when the two triphenylene fragments are sufficiently separated, ${ }^{37}$ but it has not been explored for metallate imidazolium salts or for covalent NHC metal complexes derived therefrom. Thus our main interest is structural but, furthermore, the study will report whether in these structures metal-centered luminescence is induced or not, and whether the columnar segregation preserves the triphenylene-centered luminescence unaltered.

\section{RESULTS AND DISCUSSION}

Synthesis and Characterization of Imidazolium Salts. Imidazolium salts $\mathbf{1}$ and $\mathbf{2}$ were prepared as depicted in the Scheme 1, using modified literature methods. ${ }^{37}$ Salt 1 was prepared by microwave-assisted reaction between the bromo-substituted triphenylene derivative and methyl imidazole. Salt 2 was obtained from imidazole and $\mathrm{TphBr}$ in two steps by sodiumhydride mediated nucleophilic substitution of $\mathrm{Br}$ with imidazole and subsequently microwave-assisted reaction between the triphenylene imidazole formed and a second molecule of TphBr. Both salts are air-stable white (1) or pale yellow (2) solids at room temperature. Their ${ }^{1} \mathrm{H}$ NMR spectra show, as expected, the highly low-field proton signal at ca. $11 \mathrm{ppm}$ for the acid proton in position 2 of the imidazole fragment $(\mathrm{N}-$ $\mathrm{CH}-\mathrm{N}$ ) and one (2) or two $\mathrm{CH}$ resonances (1) from the $\mathrm{CH}=\mathrm{CH}$ imidazole hydrogen atoms. Salt 1 also displays the $\mathrm{Me}-\mathrm{N}$ resonance at $4.01 \mathrm{ppm}$. In addition, the ${ }^{1} \mathrm{H}$ NMR spectra exhibit the expected signals for the substituted triphenylene group. The two salts are mesomorphic (see later).

Imidazolium bromotrichloroaurate and bromotrichloroplatinate salts $(3,4)$ were prepared by anion exchange reaction of the imidazolium salt 1 in $\mathrm{CH}_{2} \mathrm{Cl}_{2}$ solution with a water solution of $\mathrm{H}\left[\mathrm{AuCl}_{4}\right]$ or $\mathrm{K}_{2}\left[\mathrm{PtCl}_{4}\right]\left(\mathrm{Scheme}^{1)}\right.$. The reaction is finished when the color from the water phase disappears, indicating the total transfer of the metal complex to the organic phase. Both gold and platinum salts were isolated as white solids and are mesomorphic. Their ${ }^{1} \mathrm{H}$ NMR spectra show, compared to 1, a marked high-field shift for the acid N-CH-N signal. Considering that imidazolium salts have often ion-pair structures where the counteranion is hydrogen bonded to that C2 hydrogen, this difference suggests less (or non) hydrogen bond interaction in 3-4 than in $1,,^{38,39}$ as expected for the charge/size ratio of the anions. ${ }^{40}$ On the other hand, the mass spectra (see figures S15-S32) reveal that, during the anion exchange, halide exchange has occurred between the bromide provided with the imidazolium salt and the chloro ligands in the the tetrachlorometallates, producing different combinations $\left[\mathrm{MBr}_{\mathrm{m}} \mathrm{Cl}_{4-\mathrm{m}}\right]^{\mathrm{n}-}(\mathrm{m}=0-3)$. This kind of exchange has been observed before in similar circumstances. ${ }^{41}$ The existence of these different tetrahalometallate anions is not appreciable in the structural SAXS studies discussed later and its on the properties of the bulk material is probably very small.

\section{Scheme 1. Synthesis of the imidazolium salts 1-4.}

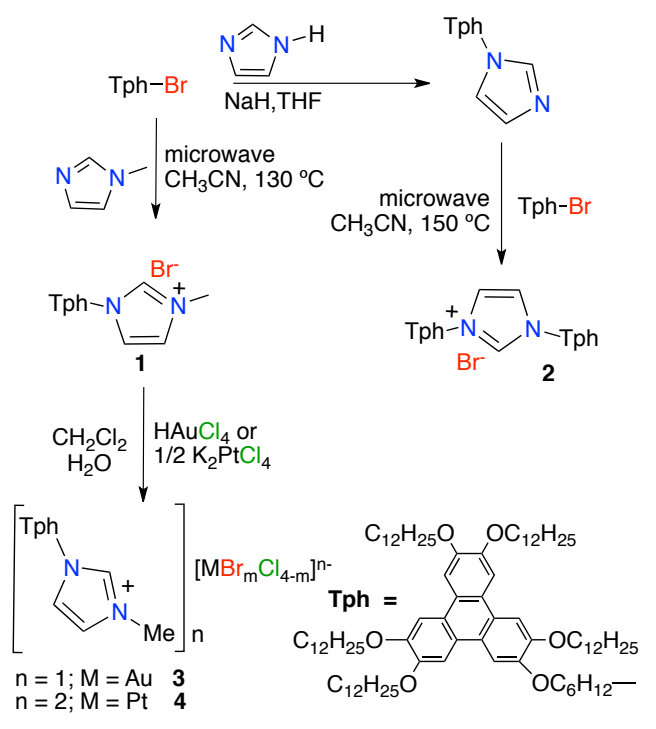

Synthesis and characterization of NHC-metal complexes. The reaction of imidazolium salts $\mathbf{1}$ and $\mathbf{2}$ with the corresponding metal oxide $\mathrm{M}_{2} \mathrm{O}(\mathrm{M}=\mathrm{Cu}, \mathrm{Ag})$ led to copper and silver $\mathrm{N}$ heterocyclic carbenes, as reported for related systems, ${ }^{42,43}$ whereas gold and platinum carbenes were obtained by transmetalation reaction of in situ prepared silver carbenes with the corresponding gold $([\mathrm{AuCl}(\mathrm{tht})](\mathrm{tht}=$ tetrahydrothiophene), $\left.[\mathrm{Au}(\mathrm{C} \equiv \mathrm{CPh})]_{\mathrm{n}}\right)$ and platinum $\left(\mathrm{K}_{2} \mathrm{PtCl}_{4}\right)$ precursors (Scheme 2). The carbene metal complexes were isolated as pale yellow (8 and 13) or white (5-7, 9-12 and 14) solids.

\section{Scheme 2. Synthesis of metal complexes 5-14. Reactions at $25^{\circ} \mathrm{C}$ unless otherwise indicated.}

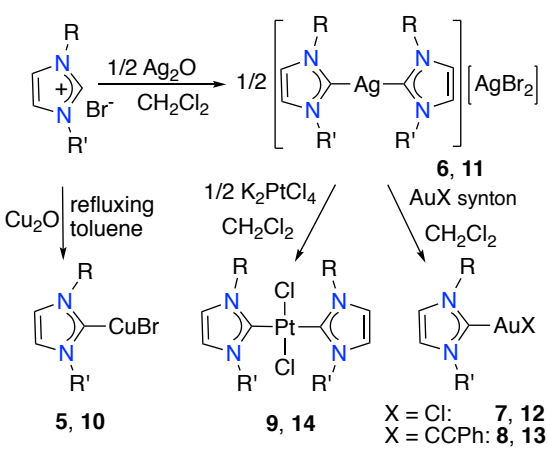

$\mathrm{R}=\mathrm{Me}, \mathrm{R}^{\prime}=\mathrm{Tph}(5-9) ; \mathrm{R}=\mathrm{R}^{\prime}=\mathrm{Tph}(\mathbf{1 0 - 1 4})$

The ${ }^{1} \mathrm{H}$ NMR spectra of the metal complexes show the disappearance of the $\mathrm{N}-\mathrm{CH}-\mathrm{N}$ signal from the imidazolium precursor, confirming the formation of the carbene complexes. The rest of resonances are similar, with some variations in chemical shift depending on the coordinated metal. The IR spectra 
of gold chloro complexes $\mathbf{7}$ and $\mathbf{1 2}$ show one $v(\mathrm{Au}-\mathrm{Cl})$ band at $329 \mathrm{~cm}^{-1}$, as expected. ${ }^{44}$ Similarly, the IR spectra of the platinum compounds $(9,14)$ display only one $v(\mathrm{Pt}-\mathrm{Cl})$ band at $c a$. $368 \mathrm{~cm}^{-1}$ corresponding to the trans isomers. ${ }^{45}$ Acetylide gold complexes $(\mathbf{8}, \mathbf{1 3})$ show the expected $v(\mathrm{C} \equiv \mathrm{C})$ absorption at $c a$. $2115 \mathrm{~cm}^{-1}$.

Thermal and mesomorphic behavior. The compounds display good thermal stability in the range of study, and have been studied using polarized optical microscopy (POM), differential scanning calorimetry (DSC), and small-angle X-ray scattering (SAXS). Optical, thermal, and thermodynamic data are gathered in Table 1. Representative microphotographs and thermograms are shown in Figures 1 and 2. Additional data are provided in the Supporting Information (Table S1 and Figures S33-S45).

Table 1. Optical, thermal and thermodynamic data of imidazolium salts and metal NHC complexes.

\begin{tabular}{llllll}
\hline $\begin{array}{l}\text { Comp. } \\
(1 \mathrm{Tph})\end{array}$ & Transition $^{\mathrm{a}}$ & $T(\Delta H)^{\mathrm{b}}$ & $\begin{array}{l}\text { Comp. } \\
(2 \mathrm{Tph})\end{array}$ & $\begin{array}{l}\text { Transi- } \\
\text { tion }^{\mathrm{a}}\end{array}$ & $T(\Delta H)^{\mathrm{b}}$ \\
\hline $\mathbf{1}$ & $\mathrm{Cr} \rightarrow \mathrm{Col}_{\mathrm{r} 1}$ & $58(56.4)$ & $\mathbf{2}$ & $\mathrm{Cr} \rightarrow \mathrm{Col}_{\mathrm{r} 2}$ & $45(66.1)$ \\
& $\mathrm{Col}_{\mathrm{r} 1} \rightarrow \mathrm{I}$ & $105(2.8)$ & & $\mathrm{Col}_{\mathrm{r} 2 \rightarrow \mathrm{I}}$ & $72(4.0)$ \\
$\mathbf{3}$ & $\mathrm{Cr} \rightarrow \mathrm{Col}_{\mathrm{r} 1}$ & $60(46.8)$ & & & \\
& $\mathrm{Col}_{\mathrm{r} 1 \rightarrow \mathrm{I}}$ & $65(4.7)$ & & & \\
$\mathbf{4}$ & ${\mathrm{Cr} \rightarrow \mathrm{Col}_{\mathrm{r} 1}} 50(69.0)$ & & & \\
& $\mathrm{Col}_{\mathrm{r} 1 \rightarrow \mathrm{Col}_{\mathrm{h}}} 100(2.4)$ & & & \\
& $\mathrm{Col}_{\mathrm{h} \rightarrow \mathrm{I}}$ & $112(4.2)$ & & &
\end{tabular}

\begin{tabular}{|c|c|c|c|c|c|}
\hline $5(\mathrm{Cu})$ & $\mathrm{Cr} \rightarrow \mathrm{I}$ & $44(44.2)$ & $10(\mathrm{Cu})$ & $\begin{array}{l}\mathrm{Cr} \rightarrow \mathrm{Col}_{\mathrm{r} 2} \\
\mathrm{Col}_{\mathrm{r} 2} \rightarrow \mathrm{I}\end{array}$ & $\begin{array}{l}45(81.2) \\
70(2.7)\end{array}$ \\
\hline $6(\mathrm{Ag})$ & $\begin{array}{l}\mathrm{Cr} \rightarrow \mathrm{Col}_{\mathrm{r} 2} \\
\mathrm{Col}_{\mathrm{r} 2} \rightarrow \mathrm{I}\end{array}$ & $\begin{array}{l}55 \\
(106.3) \\
98(4.6)\end{array}$ & $11(\mathrm{Ag})$ & $\begin{array}{l}\mathrm{Cr} \rightarrow \mathrm{Col}_{\mathrm{r} 2} \\
\mathrm{Col}_{\mathrm{r} 2} \rightarrow \mathrm{I}\end{array}$ & $\begin{array}{l}43 \\
(132.1) \\
62(5.5)\end{array}$ \\
\hline $7(\mathrm{Au})$ & $\mathrm{Cr} \rightarrow \mathrm{I}$ & $45(46.9)$ & $12(\mathrm{Au})$ & $\mathrm{Cr} \rightarrow \mathrm{I}$ & $46(89.5)$ \\
\hline $8(\mathrm{Au})$ & $\mathrm{Cr} \rightarrow \mathrm{I}$ & $45(55.4)$ & $13(\mathrm{Au})$ & $\mathrm{Cr} \rightarrow \mathrm{I}$ & $25(65.8)$ \\
\hline $9(\mathrm{Pt})$ & $\begin{array}{l}\mathrm{Cr} \rightarrow \mathrm{Col}_{\mathrm{r} 2} \\
\mathrm{Col}_{\mathrm{r} 2} \rightarrow \mathrm{I}\end{array}$ & $\begin{array}{l}50(93.6) \\
76(4.7)\end{array}$ & $14(\mathrm{Pt})$ & $\begin{array}{l}\mathrm{Cr} \rightarrow \mathrm{Col}_{\mathrm{r} 2} \\
\mathrm{Col}_{\mathrm{r} 2} \rightarrow \mathrm{I}\end{array}$ & $\begin{array}{l}30(18.7) \\
57(5.4)\end{array}$ \\
\hline
\end{tabular}

${ }^{a} \mathrm{Cr}$, crystal phase; $\mathrm{Col}_{\mathrm{r}}$, rectangular columnar mesophase; $\mathrm{Col}_{\mathrm{h}}$, hexagonal columnar mesophase; I, isotropic liquid. ${ }^{\circ}{ }^{\circ} \mathrm{C}\left(\mathrm{kJ} \mathrm{mol}^{-1}\right)$. Data from second heating DSC cycle. Transition temperatures are given as peak onsets, with associated enthalpy changes between brackets.

The four imidazolium salts (1-4), as well as the copper (10), platinum $(9,14)$ and silver $(6,11)$ carbene complexes, display enantiotropic mesomorphism with melting points in the range $30-60{ }^{\circ} \mathrm{C}$. Figure 1 shows two representative thermograms. In contrast, the gold carbene complexes $(7,8,12,13)$ and the copper derivative $\mathbf{5}$ (which contains only one Tph group) melt directly to an isotropic liquid.
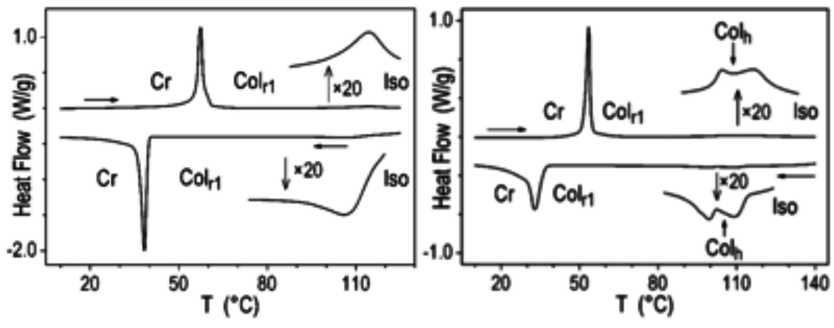

Figure 1. Representative DSC thermograms $\left(5^{\circ} \mathrm{C} / \mathrm{min}\right.$, endotherm up) of imidazolium salts 1 (left) and 4 (right). The DSC thermograms of the other compounds can be found in the Supporting Information (Figures S33-S38).

The textures observed by POM on cooling from the isotropic liquid are fluid and birefringent, and similar for all the mesomorphic compounds in Table 1, but rather unspecific. However, pseudo-focal conic textures suggesting columnar mesophases were observed (Figure 2) when using hydrophilic glass (treated with sulfochromic mixture). This was confirmed in the SAXS studies.

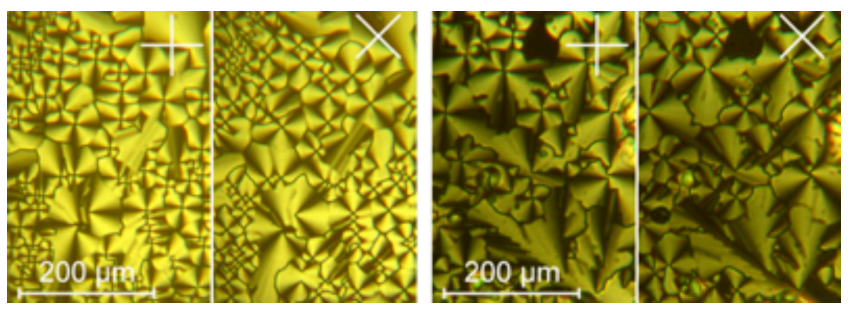

Figure 2. Optical polarizing microscopy photographs recorded on cooling from the isotropic phase using hydrophilic glass treated with sulfochromic mixture, for two different directions of crossed polarizers (given by the white crosses). Left, imidazolium salt 1 at $70{ }^{\circ} \mathrm{C}$; right, the corresponding silver carbene 6 at $70{ }^{\circ} \mathrm{C}$.

SAXS Studies. As shown above by POM and DSC, the imidazolium salts (1-4), and five of the ten carbene complexes (6, 9-11, and 14) exhibit liquid crystalline mesophases. The emergence of columnar mesophases with large superlattice structures, containing several columns per lattice (multicolumnar mesophases, see below), was confirmed by SAXS investigation. The structure of the mesophases was solved from the indexation of the series of sharp reflections in the small-angle range of the SAXS patterns (Figure 3, Table S1). These patterns also reveal broad wide-angle scattering maxima that correspond to: liquid-like lateral distances between aliphatic chains and spacers $\left(\mathrm{h}_{\mathrm{ch}}\right)$; piled triphenylene units orthogonally stacked over short distances $\left(\mathrm{h}_{\mathrm{Tph}}\right.$ and dimer periodicity $\mathrm{h}_{\mathrm{Tph}, 2} \approx$ $2 \times \mathrm{h}_{\mathrm{Tph}}$ ); and imidazolium salts (or carbene complexes, both referred to as Im in the text) species (row periodicities $\mathrm{h}_{\mathrm{Im}}$ and $\mathrm{h}_{\text {Im,2 }} \approx 2 \times \mathrm{h}_{\text {Im }}$, see below), undifferentiated from the chains, and thus overlapping with $h_{\text {ch }}$. Neither the copper complex 5 nor the gold complexes $(7, \mathbf{8}, \mathbf{1 2}$, and 13$)$ are liquid-crystalline. Nevertheless, the SAXS patterns in the isotropic liquid phase (Iso) exhibit a broad small-angle peak $\mathrm{D}$, due to the nanosegregation occurring at the local-range level between the chains, the Tph and the Im moieties, together with a broad wide-angle scattering $\mathrm{h}_{\text {lat }}$ from overlapping lateral distances between molecular moieties (Table S1 and Figures S39-S45 in Supporting Information).

Based on a discerning analysis of the SAXS patterns, three types of mesophase were overall found in the liquid crystalline compounds, namely: two rectangular columnar mesophases of different symmetries, $\mathrm{Col}_{\mathrm{r} 1}(\mathrm{c} 2 \mathrm{~mm})$ and $\mathrm{Col}_{\mathrm{r} 2}(p 2 \mathrm{mg})$ respectively, and a columnar phase with hexagonal symmetry $(p 6 \mathrm{~mm}), \mathrm{Col}_{\mathrm{h}}$ (Table 2 and Table $\mathrm{S} 1$ in Supporting Information). The numerous sharp, small-angle reflections (from 6 to 11 diffraction peaks, Figure 3 and Figures S39-S45 in Supporting Information), systematically observed for all compounds, along with the modulation of the intensity distribution, indicated the long-range two-dimensional expansion of 
the rectangular lattices ( $c 2 \mathrm{~mm}$ and $p 2 \mathrm{mg}$ ), and confirmed the good segregation between the various molecular constituents, namely, the triphenylene discs, the Im species (together with the metallic fragments in the affirmative cases), and the aliphatic continuum, respectively. As expected, mesomorphism induction is primarily driven by the strong tendency of the triphenylene units to stack into one-dimensional columns and to nanosegregate from peripheral alkyl chains, as well as by metallic and imidazole fragments confined in separate zones, but the corresponding supramolecular organizations obviously need to find a compromise between arrangements and natural distances in Im and Tph zones, which are not necessarily compatible and impose stoichiometry constraints. The results are the large-size lattices of various symmetries, the widening of the scattering maxima and the reduced correlation lengths associated to piling. Since the metallic and imidazole fragments are directly connected together, either by ionic interactions in the salts $\mathbf{3}$, and $\mathbf{4}$ or by covalent bonds in the carbene complexes, they necessarily aggregate into undifferentiated columns or threads. The supramolecular organization into such multicolumnar mesophases would then consist of the concerted arrangement of both types of columns, the hybrid imidazole-metal based columns localized at the nodes of the twodimensional lattices, and the triphenylene columns forming a continuous sub-network within the lattices. The molten chains, merged into an infinite continuum (Figure 4), fill the space between columns. This prevents to deduce any individual connectivity between Tph and Im groups, because it occurs via these molten chains.

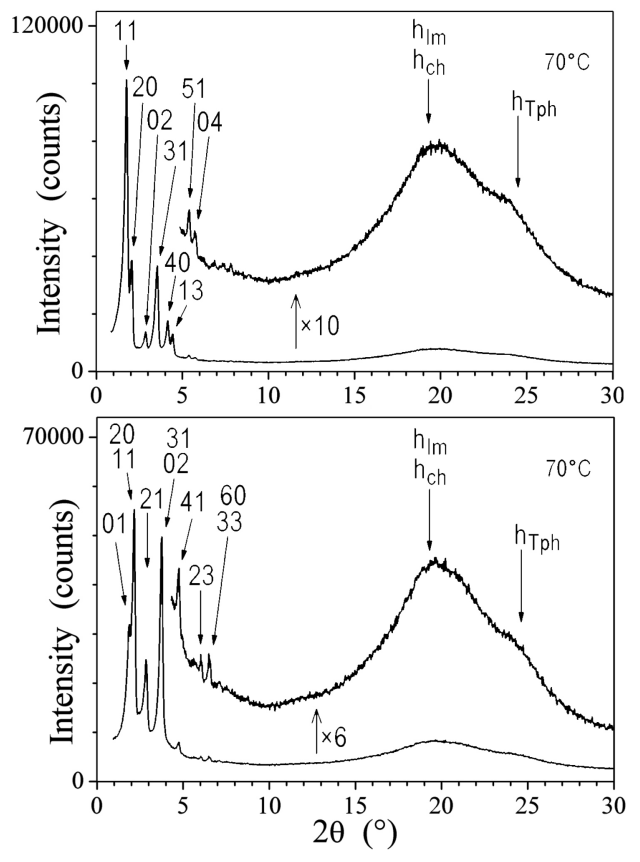

Figure 3. SAXS diffractograms of the imidazolium salts 1 (top) and 2 (bottom), shown as representative examples. The SAXS patterns for the other derivatives are shown in the Supporting Information (Figures S39-S45).

Using a geometrical model previously reported, ${ }^{32}$ it is possible to have more details about the specific internal organizations of the various parts within the mesophase lattices. The ratio between the molecular volume and the lattice area (with $Z=2$, for the rectangular symmetry, and $Z=1$ for hexagonal symmetry) and weighted by $N_{\text {mol }}$ molecules per repeat patterns (varying with the metal complexes connectivity, Table 2) provides a value for $h_{\text {mol }}$ ranging around the value of $h_{T p h}$, consistent with a nearly orthogonal stacking of the triphenylene discs in the columns.

The imidazolium salts with 1:1 Im:Tph stoichiometry (1, 3, and 4) show a centered rectangular columnar mesophase $\mathrm{Col}_{\mathrm{r} 1}$, in agreement with the $c 2 \mathrm{~mm}$ planar symmetry $\left(\mathrm{Col}_{\mathrm{r} 1}, \mathrm{c} 2 \mathrm{~mm}\right)$, with a shrunken row spacing (i.e. $a / b \approx 1.38<\sqrt{3}$ ). From this analysis, the number of Tph columns per lattice, $Z_{\mathrm{Tph}}$, is found to be most likely 8 . This was solved by trial-error tests, and keeping the most logical solution respecting the various symmetry elements of the planar group (see details in Table 2). Hence the average piling distance of Tph mesogens $\left(\mathrm{h}_{\mathrm{Tph}}=\right.$ 3.6-3.8 $\AA$ ) is in agreement with their periodicity along columns (determined from molecular volume and lattice area ratio: $\mathrm{h}_{\text {mol }}=3.7-3.8 \AA$, Table 2). At higher temperature, the imidazolium salt 4 exhibits a transition from $\mathrm{Col}_{\mathrm{r} 1}$ to hexagonal columnar $\left(\mathrm{Col}_{\mathrm{h}}\right)$ phase with presumably $Z_{\mathrm{Tph}}=3$ (or 4$) \mathrm{Tph}$ columns per lattice.

The imidazole derivatives with Im:Tph composition in 1:2 stoichiometry $(\mathbf{2}, \mathbf{1 0}, \mathbf{1 1}, \mathbf{1 4})$, and $1: 1$ stoichiometry $(\mathbf{6}, 9)$ show a primitive rectangular columnar mesophase, with a pseudo-hexagonal geometry (i.e. $a / b \approx \sqrt{ } 3$ ). The reflections series involves (01), (41), (23), with odd $h+k$ sum demonstrating the primitive lattice. The presence of the reflection (01) moreover proves the absence of glide line along $b$-axis. The highest possible and most likely planar symmetry is hence $p 2 m g$, with glide lines parallel to $a$-axis $\left(\mathrm{Col}_{\mathrm{r} 2}, p 2 m g\right)$. The number of Tph columns per lattice is most likely $\mathrm{Z}_{\mathrm{Tph}}=6$, which is compatible with the phase symmetry and leads to agreement between $\mathrm{h}_{\text {mol }}$ and $\mathrm{h}_{\mathrm{Tph}}$ values as for $\mathrm{Col}_{\mathrm{r} 1}$ (Table 2).

Table 2. Geometrical and structural parameters of the mesophases obtained from SAXS.

\begin{tabular}{|c|c|c|c|c|}
\hline LC's & $\mathrm{T} /{ }^{\circ} \mathrm{C}$ & $\begin{array}{l}\mathrm{a}, \mathrm{b}[\AA] \\
\mathrm{a} / \mathrm{b} \\
A\left[\AA^{2}\right] \\
(\mathrm{Z})\end{array}$ & $\begin{array}{l}\mathrm{V}_{\mathrm{mo}} 1\left[\AA^{3}\right] \\
h_{\mathrm{mol}}[\AA] \\
N_{\mathrm{mol}}\end{array}$ & $\begin{array}{l}\mathrm{Z}_{\mathrm{Tph}}\left(n_{\mathrm{Tph}}\right) \\
\mathrm{h}_{\mathrm{Tph}}[\AA] \\
\xi[\AA]\end{array}$ \\
\hline 1 & 70 & $\begin{array}{l}85.3 \\
61.7 \\
1.38 \\
5260(2) \\
\end{array}$ & $\begin{array}{l}2420 \\
3.68 \\
4\end{array}$ & $\begin{array}{l}8(1) \\
3.70 \\
20\end{array}$ \\
\hline 2 & 70 & $\begin{array}{l}81.0 \\
47.0 \\
1.72 \\
3810(2)\end{array}$ & $\begin{array}{l}4620 \\
3.64 \\
1.5\end{array}$ & $\begin{array}{l}6(2) \\
3.65 \\
20\end{array}$ \\
\hline 3 & 60 & $\begin{array}{l}85.1 ; \\
61.3 \\
1.39 \\
5220(2)\end{array}$ & $\begin{array}{l}2490 \\
3.80 \\
4\end{array}$ & $\begin{array}{l}8(1) \\
7.40 \\
25^{*}\end{array}$ \\
\hline 4 & 60 & $\begin{array}{l}84.8 \\
61.4 \\
1.38 \\
5210(2)\end{array}$ & $\begin{array}{l}2430 \\
3.73 \\
4\end{array}$ & $\begin{array}{l}8(1) \\
7.35 \\
35 *\end{array}$ \\
\hline & $\overline{110}$ & $\begin{array}{l}49.9 \\
- \\
2160(1) \\
\end{array}$ & $\begin{array}{l}2520 \\
3.5 \\
3 \\
\end{array}$ & $\begin{array}{l}3(1) \\
7.50 \\
20 * \\
\end{array}$ \\
\hline 6 & 70 & $\begin{array}{l}83.8 \\
49.0 \\
1.71 \\
4110(2) \\
\end{array}$ & $\begin{array}{l}4880 \\
3.56 \\
1.5\end{array}$ & $\begin{array}{l}6(2) \\
3.70 \\
20\end{array}$ \\
\hline 9 & 70 & 83.8 & 4770 & $6(2)$ \\
\hline
\end{tabular}




\begin{tabular}{lllll}
\hline & 48.6 & 3.51 & 3.65 \\
& & 1.72 & 1.5 & 20 \\
& & $4070(2)$ & & $6(2)$ \\
$\mathbf{1 0}$ & 50 & $81.0 ;$ & 4570 & 3.60 \\
& & 47.3 & 3.58 & 20 \\
& & 1.71 & 1.5 & \\
\hline $\mathbf{1 1}$ & 50 & $81.1 ;$ & 9140 & $6(4)$ \\
& & 47.3 & 3.57 & 3.60 \\
& & 1.71 & 0.75 & 25 \\
& & $3840(2)$ & & \\
\hline $\mathbf{1 4}$ & 55 & $80.9 ;$ & 8260 & $6(4)$ \\
& & 47.0 & 3.26 & - \\
& & 1.72 & 0.75 & - \\
& $3800(2)$ & & \\
\hline
\end{tabular}

\begin{tabular}{llllll}
\hline Non LC's & $\mathrm{T} /{ }^{\circ} \mathrm{C}$ & $\mathrm{D} / \AA(\xi / \AA)$ & & $\mathrm{T} /{ }^{\circ} \mathrm{C}$ & $\mathrm{D} / \AA(\xi / \AA)$ \\
\hline $\mathbf{5}$ & 75 & $55(110)$ & - & - & - \\
$\mathbf{7}$ & 70 & $37(50)$ & $\mathbf{1 2}$ & 75 & $36(60)$ \\
$\mathbf{8}$ & 70 & $40(60)$ & $\mathbf{1 3}$ & 70 & $35(40)$
\end{tabular}

T: temperature at which the SAXS pattern was recorded; $a$ and $b$ are the columnar lattice parameters in $\AA, A$ is the lattice area in $\AA^{2}$ $\left(A=a \times \mathrm{b}\right.$ for $\mathrm{Col}_{\mathrm{r}}$, and $2 a^{2} / \sqrt{3}$ for $\mathrm{Col}_{\mathrm{h}}$ ) and $Z$, is number of repeat pattern per lattice; $\mathrm{V}_{\text {mol }}$ : molecular volume calculated from reference dilatometric measurements, ${ }^{46} h_{\mathrm{mol}}$ is the thickness of the repeat pattern slice involving $N_{\mathrm{mol}}$ molecules, $h_{\mathrm{mol}}=\mathrm{V}_{\mathrm{mol}} \times N_{\mathrm{mol}} /(A / Z) ; Z_{\mathrm{Tph}}$ is the number of Tph columns per lattice $\left(Z_{\mathrm{Tph}}=Z \times N_{\mathrm{mol}} \times n_{\mathrm{Tph}}\right)$, where $n_{\mathrm{Tph}}$ is the number of triphenylene groups per molecule. $\mathrm{h}_{\mathrm{Tph}}$ $(\xi)$ : distance between piled Tph mesogens from the position of the corresponding wide-angle scattering maximum and correlation length associated to piling $\left({ }^{*} \mathrm{~h}_{\mathrm{Tph}}\right.$ not measurable, indicated instead: position and $\xi$ of the intense signal from second Tph distance $\mathrm{h}_{\mathrm{Tph}, 2}$ and/or ionic layer periodicity $h_{\operatorname{Im}, 2}$ ). Temperature of isotropic liquid at which pattern was obtained; D $(\xi)$, short-range correlated periodicity and associated correlation length from Scherrer equation.

Note that the kind of mesophase is not determined by the Im:Tph ratios, since $\left(\mathrm{Col}_{\mathrm{r} 2}, p 2 m g\right)$ is formed by complexes with different stoichiometries. The most plausible supramolecular arrangements in the three kinds of mesophase, compatible with the SAXS data, are shown in Figure 4. In this figure the red disks correspond to triphenylene columns, and the green petals to imidazole-anion or carbene-metal zones. The aliphatic chains, occupying the white areas, have no order and are not shown for clarity.

The results show that some compounds with different Tph:Im or Im:anion proportions give rise, however, to the same columnar symmetry $\left(\mathrm{Col}_{\mathrm{r} 2}, \mathrm{p} 2 \mathrm{mg}\right.$ in this case), which deserves some comments. Figure 4 is meant to illustrate the average symmetry of the Tph and Im zones, not the stoichiometric Tph:Im or Im:anion proportions. The picture is viewed from above the Tph columns, which are constituted by a regular piling of Tph discs. However the petals are meant only to show the average symmetry of their piling along their column, not the Tph:Im proportion. This means that half of the petals depicted can be in one layer and be missing in the next one, when Tph:Im $=2: 1$. For instance, for the compounds with $\left(\mathrm{Col}_{\mathrm{r} 1}, c 2 \mathrm{~mm}\right)$ symmetry and Tph:Im $=1: 1$ the graphical representation in Figure 4 is correct considering that all the petals represented are in all layers, as defined by the Tph groups. However, for the complexes with Tph:Im $=2: 1\left(\mathrm{Col}_{\mathrm{r} 2}, p 2 m g\right.$ symmetry) we have to consider that each petal appears, randomly, only every two layers along the piling direction, but producing an average symmetry as indicated. Similar consid- erations apply to the Im:anion proportions in the salts. Thus, in the $\mathrm{Col}_{\mathrm{h}}$ mesophase ( $\mathrm{p} 6 \mathrm{~mm}$ symmetry) of $\mathbf{4}$ at higher temperature, six petals are indicating average hexagonal symmetry, and do represent the 1:1 Tph:Im proportion, but the number of $\left[\mathrm{PtBr}_{\mathrm{m}} \mathrm{Cl}_{4-\mathrm{m}}\right]^{2-}$ counteranions is only one every two Tph-Im groups. The type of lattice depends on the Tph:Im proportion and on the internal structure of the columns of ions or of NHC-metal complexes, and a phase transition from $\mathrm{c} 2 \mathrm{~mm}$ to p6mm even occurred for 4 , presumably because of a modified internal structure allowing a re-distribution of the columns in the lattice plane.

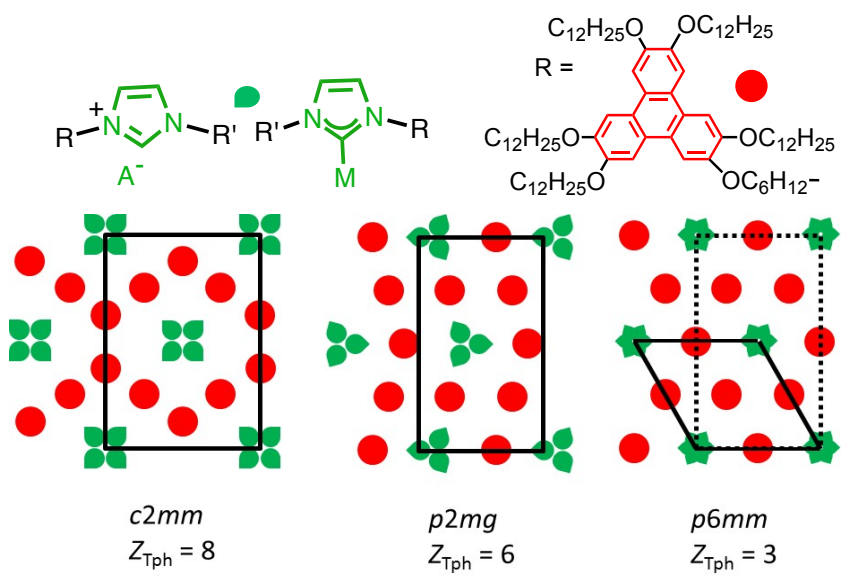

Figure 4. Proposed packing for the $\mathrm{Col}_{\mathrm{r} 1}$ mesophase $(\mathrm{c2mm}$ symmetry, Tph:Im = 1:1), the $\mathrm{Col}_{\mathrm{r} 2}$ mesophase (p2mg symmetry, Tph:Im $=1: 1,2: 1)$, and the $\mathrm{Col}_{\mathrm{h}}$ mesophase $(p 6 \mathrm{~mm}$ symmetry, $T p h / I m=1: 1$ ), viewed from above the columns. The red disks correspond to triphenylene columns, and the green petals to Im zones; the aliphatic chains, occupying the white areas, are not shown for clarity. Note that the picture formed by the association of green petals does not follow the variable Tph:Im proportions, but shows the average symmetry of aggregated Im columns and of their connections to Tph columns (see text)

Discussion of the self-organization behavior. The absence of mesomorphism in compounds $\mathbf{8}$ and $\mathbf{1 3}$ is due to the presence of the protruding phenylacetylene group that will disturb the regular arrangement of the piled molecular segments into the columnar lattice. The reason is more puzzling for the gold and copper carbenes 5, 7 and 12, which do not differ structurally from their free-metal, silver and copper counterparts $(\mathbf{1}-\mathbf{4}, \mathbf{6}$, 10-11), which suggests that other crucial parameters in addition to the Im-Tph stoichiometry, such as the specific interactions between metallic species and the metal coordination nature (type and geometry) must also be decisive.

The mesomorphic behavior confirmed by the SAXS studies can be discussed based on the simple enthalpy/entropy (disks/molecule) analysis of the molecular self-assembly process that we introduced recently. ${ }^{32}$ Considering that in a molecular self-assembly process, a decrease in entropy always occurs $(\Delta S<0)$, the supramolecular structure (in our case the mesophase) will only be formed when the magnitude of attractive molecular interactions compensates for the unfavorable entropic term of the process $(|\Delta \mathrm{H}|>|\mathrm{T} \Delta \mathrm{S}|)$ to give rise to a decrease in the free energy of the system. Hence, all the ionic salts $\mathbf{1}-\mathbf{4}$, where in addition to $\pi-\pi$ stacking contributions of the triphenylene groups attractive electrostatic interactions are 
operating, show mesomorphic behavior. In fact, the analogous non-ionic imidazole-pentyloxy triphenylene derivative is non mesomorphic, whereas the corresponding bromide salt is liquid crystal. $^{37 \mathrm{c}}$

Concerning the effects on the thermal properties of replacing bromide by a $\left[\mathrm{MCl}_{4}\right]^{\mathrm{n}-}$ counteranion, the variations are fairly regular. The melting points are quite insensitive to the anion present in the system, whereas the clearing points decrease in the order $\left[\mathrm{PtBr}_{\mathrm{m}} \mathrm{Cl}_{4-\mathrm{m}}\right]^{2-}>\mathrm{Br}^{-}>\left[\mathrm{AuBr}_{\mathrm{m}} \mathrm{Cl}_{4-\mathrm{m}}\right]^{-}$. This behavior fits well the model that considers that the crystal-to-discotic phase transition is associated to disordering the peripheral chains, whereas the clearing transition requires collapse of the stacking of the cores in the columnar structure. In this model, the substitution of $\mathrm{Br}^{-}$by the tetrahaloaurate group, with the same total charge but distributed in a bulkier molecule, should produce a decrease of the clearing temperatures, as observed. In contrast, the tetrahaloplatinate anion, with a higher charge, might produce stronger electrostatic interactions inducing a stabilization of the columnar stacking and higher clearing temperatures.

For the carbene complexes, the enthalpy/entropy balance should favor mesomorphic behavior in molecules with a greater number of triphenylene groups per molecule, since this increases the number of $\pi-\pi$ stacking interaction without sensibly increasing the unfavorable entropic contribution. Consistently, the liquid crystal behavior found for the neutral platinum complexes 9 and $14(\mathrm{Tph} /$ molecule $=2$ or 4 , respectively) is expected, as for related systems. ${ }^{32}$ For the ionic silver compounds 6 and $11(\mathrm{Tph} /$ molecule $=2$ or 4 , respectively, plus ionic interactions) the mesomorphic behavior is also not unexpected. The interesting difference in thermal behavior is found when comparing the copper and gold complexes, with apparently identical structures. The presence of the alkynyl group in the gold complexes $\mathbf{8}$ and $\mathbf{1 3}$ is structurally detrimental compared to the presence of $\mathrm{Cl}$ in 7 and $\mathbf{1 2}$, but none of them is mesomorphic. In contrast, for the similar copper compounds 5 and $10(\mathrm{Tph} /$ molecule $=1$ or 2 , respectively) the latter, with a more favorable $\mathrm{Tph} / \mathrm{molecule}$ ratio displays mesomorphism. As we discussed recently somewhere else, the molecular dipoles associated to the $\mathrm{M}-\mathrm{X}$ dipoles can induce these molecules to behave as dimers induced by dipole-dipole interactions, multiplying by two the $\mathrm{Tph} / \mathrm{molecule}$ ratios. ${ }^{32}$ According to the dipole moments of $\mathrm{Au}-\mathrm{Cl}$ (4.91 D) and $\mathrm{Cu}-$ $\mathrm{Br}(5.55 \mathrm{D})$ bonds in the monohalides (MRCISD method), ${ }^{47}$ and also to the data of Pauling electronegativity of the atoms involved (1.90 for $\mathrm{Cu}^{\mathrm{I}}, 2.54$ for $\mathrm{Au}^{\mathrm{I}}, 2.96$ for bromine and 3.16 for chlorine $),{ }^{48}$ and the $\mathrm{M}-\mathrm{X}$ distances $(\mathrm{Au}-\mathrm{Cl} \approx 2.38 \AA ; \mathrm{Cu}-$ $\mathrm{Br} \approx 2.54 \AA),{ }^{49}$ the $\mathrm{Cu}^{\mathrm{I}}-\mathrm{Br}$ dipole is expected to be somewhat higher than the $\mathrm{Au}^{\mathrm{I}}-\mathrm{Cl}$ dipole, although only in the most favorable complex $\mathbf{1 0}$ this circumstance is decisive to produce mesomorphism.

Photophysical behavior. All the electronic spectra are very similar with absorption bands and extinction coefficients typical of triphenylene chromophores (Table S2 and Figure S46 in Supporting Information). ${ }^{30,50}$ The luminescent properties of the new imidazolium salts and metal carbenes have been studied in $\mathrm{CH}_{2} \mathrm{Cl}_{2}$ solution, in the solid state ( $\mathrm{KBr}$ dispersion), in the mesomorphic state, and in the isotropic liquid. The results are summarized in Tables S3-S4 of Supporting Information. Representative examples are shown in Figure 5.
In dichloromethane solution, the compounds display an intense blue emission visually observed under a UV lamp (365 $\mathrm{nm}$ ) at room temperature. Solutions from $10^{-7} \mathrm{M}$ to $10^{-2} \mathrm{M}$ display the same emission, which confirms that emission is not related to agglomeration. All the emission spectra are similar showing a structured pattern with the maximum at $c a .387 \mathrm{~nm}$ and emission time decay in the range of nanoseconds $(\tau=8.97$ ns \pm 0.03 measured for $\mathbf{1}$ as a representative example). This is typical of triphenylene-centered fluorescence. ${ }^{50}$ In the solid state ( $\mathrm{KBr}$ dispersion), all the compounds display emission patterns similar to the dichloromethane solution ones, but their intensity decreases noticeably as described for related systems. $^{31}$ The, emissions show vibronics separated 1250-1360 $\mathrm{cm}^{-1}$ confirming that they are directly related to the aromatic core of triphenylene. Lifetime measurements were recorded for 1 as a representative example, affording an emission time decay $\tau=11.82 \pm 0.04 \mathrm{~ns}$ (385 $\mathrm{nm}$ emission; excitation LED $320 \mathrm{~nm}$ ). Again, this supports that luminescence is related to the triphenylene core with scarce influence of the metallic fragments.

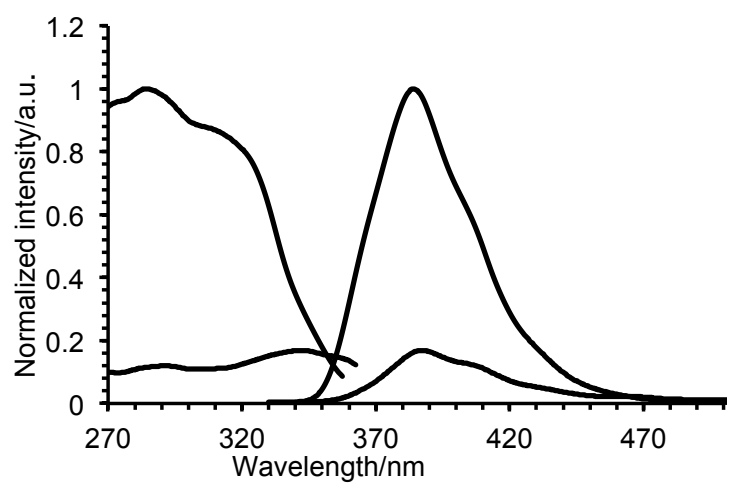

Figure 5. Dichloromethane solution (more intense) and solidstate (less intense) excitation and emission spectra of compound 1 at $298 \mathrm{~K}$.

Finally, the luminescence of the mesomorphic compounds was measured at variable temperature to examine the luminescence in the solid, the mesophase, and isotropic liquid states (Figure S47). Interestingly, the compounds are luminescent in the three states. At the melting point all the compounds show a slight decrease of the emission intensity observed in the solid. The same is observed at the clearing point to the isotropic liquid. The process is reversible, and the intensity of the emission is gradually recovered upon cooling. There is no induced luminescence by special packing in the liquid crystal. Thus, the luminescent behavior found in our complexes is centered on the triphenylene core and it is independent of the state of aggregation, suggesting that self-assembling of the triphenylene fragments is weak. This is in agreement with the fact that our compounds do not display high clearing temperatures, which reveals that intermolecular interactions in the mesophase are not strong.

\section{CONCLUSIONS}

The study of the triphenylene-imidazolium salts and their related triphenylene-carbene-metal complexes shows very clearly that the $\pi$-stacking of the triphenylene discs in columns is the essential driving force to define the segregation occurring in the mesophase. The Im-metal zone also presents co- 
lumnar order. The nature of the interactions in the Im-metal columnar zone is less important to define the kind of symmetry adopted by the material (identical phases can be produced by ionic salts or by covalent complexes). This does not mean that this part of the molecule is not influencing the formation of mesophases: these ionic or dipolar interactions are clearly a decisive contribution on occasions where a smaller enthalpic contribution by the Tph $\pi$-stacking contribution (in complexes with Tph:Im $=1: 1$ ratio) is insufficient provide a favorable condition for self-assembly $(|\Delta \mathrm{H}|>|\mathrm{T} \Delta \mathrm{S}|)$, as in the case of the copper complex $\mathbf{1 0} v s$. the gold complex 12.

The emission spectra are fully related to the triphenylene core, which is electronically little influenced by the Im-metal moiety. The fact is that the emission spectra suffer only moderate intensity changes with changes of the physical state. This may allow monitoring the presence of the core through experiments where the physical condition of the complexes might be changing.

\section{EXPERIMENTAL SECTION}

General Considerations. General procedures are as reported before. ${ }^{32}$ IR spectra were recorded on a Perkin-Elmer Frontier spectrometer coupled to a Pike GladiATR-210 accessory $\left(4000-200 \mathrm{~cm}^{-1}\right) .{ }^{1} \mathrm{H}$ NMR spectra were recorded on $\mathrm{CDCl}_{3}$ solutions in Bruker AV-400 $(400.13 \mathrm{MHz})$ or Varian $500(499.73 \mathrm{~Hz})$ instruments; chemical shifts are quoted relative to $\mathrm{SiMe}_{4}$ (external, $\left.{ }^{1} \mathrm{H}\right)$. Elemental analyses were performed with a Perkin-Elmer 2400 microanalyser. Absorption spectra were recorded on a UV-2550 Shimadzu spectrophotometer. Emission and excitation spectra at $298 \mathrm{~K}$ were measured in the solid state as finely pulverized $\mathrm{KBr}$ mixtures, in deoxygenated $\mathrm{CH}_{2} \mathrm{Cl}_{2}$ solutions in quartz tubes and in the mesophase by means of a remote fiber optic accessory with the sample placed between two quartz plates using silica spacers $(30 \mu \mathrm{m})$ to maintain the cell gap, and the Mettler FP-82HT hot stage with a Perkin-Elmer LS-55 spectrofluorimeter. Lifetime measurements were recorded with a Datastation HUB-B with a nanoLED controller and software DAS6. The lifetime data were fitted using the Jobin-Yvon software package. MALDITOF mass spectrometry was carried out in Bruker Autoflex instrument. Microwave reactions were carried out using a CEM Focused Microwave Synthesis System, Model Discover instrument. Polarized Light Optical Microscopy was performed with a Leica DMRB microscope equipped with a hot stage Mettler Toledo FP 90. Differential Scanning Calorimetry was performed with a Perkin Elmer DSC-7 instrument calibrated with Indium as reference (mp: $156.6{ }^{\circ} \mathrm{C}$, $\Delta \mathrm{H}=28.4 \mathrm{~J} / \mathrm{g}$ ) and water, the thermograms were recorded at $5 \% \mathrm{~min}$. Microbalance Perkin Elmer was used to weight the samples. Temperature-variable small-angle $\mathrm{X}$-ray patterns were obtained using a linear focalized monochromatic $\mathrm{Cu}-\mathrm{K} \alpha 1$ beam $(\lambda=1.5405 \AA)$ using a sealed-tube generator $(900 \mathrm{~W})$ equipped with a bent quartz monochromator. In all cases, the crude powder was filled in thin Lindemann capillaries of $1 \mathrm{~mm}$ diameter and $10 \mu \mathrm{m}$ wall thickness in air (corrections for air were made), and then heated to produce the mesophase. An initial set of diffraction patterns was recorded with a curved Inel CPS 120 counter gas-filled detector linked to a data acquisition computer; periodicities up to $70 \AA$ can be measured, and the sample temperature controlled to within $\pm 0.01{ }^{\circ} \mathrm{C}$ from 20 to 200 ${ }^{\circ} \mathrm{C}$. Alternatively, patterns were also recorded on an image plate; periodicities up to $120 \AA$ can be measured (scanned by STORM 820 from Molecular Dynamics with $50 \mathrm{~mm}$ resolution).

Synthesis of the Precursors. Literature methods were used to prepare $[\mathrm{AuCl}(\mathrm{tht})],{ }^{51}[\mathrm{Au}(\text { phenylacetylide })]_{\mathrm{n}},{ }^{52}$ and the ligands, 2(hydroxy)-3,6,7,10,11-pentakis(dodecyloxy)triphenylene and 2-((6bromohexyl)oxy)-3,6,7,10,11-pentakis(dodecyloxy)triphenylenes. ${ }^{32}$

The other reagents were obtained from commercial sources. Labels $\left(\mathrm{Im}^{1 \mathrm{Tph}}\right),\left(\mathrm{Im}^{2 \mathrm{Tph}}\right),\left(\mathrm{NHC}^{1 \mathrm{Tph}}\right)$ and $\left(\mathrm{NHC}^{2 \mathrm{Tph}}\right)$ are used to indicate the imidazolium cation and the NHC derived from the initial imidazolium salts with 1 or 2 triphenylene units in the compounds.
Synthesis
of
1-methyl-3-(6-((3,6,7,10,11pentakis(dodecyloxy)triphenylen-2-yl)oxy)hexyl)-imidazolium

bromide, $\left(\mathbf{I m}^{1 \mathrm{Tph}}\right) \mathrm{Br}$, 1. A mixture of 2-((6-bromohexyl)oxy)3,6,7,10,11-pentakis(dodecyloxy)triphenylene ( $80 \mathrm{mg}, 0.06 \mathrm{mmol}$ ) and methyl imidazole $(24.6 \mathrm{mg}, 0.3 \mathrm{mmol})$ in acetonitrile was stirred in a microwave instrument at $130{ }^{\circ} \mathrm{C}$ during $1 \mathrm{~h}$ at $300 \mathrm{~W}$. The resulted white solid was filtered and washed with acetonitrile to obtain the desired product. Yield: $79.3 \mathrm{mg}, 93 \%$. Anal. Calcd for $\mathrm{C}_{88} \mathrm{H}_{149} \mathrm{BrN}_{2} \mathrm{O}_{6}$ : C, 74.91; $\mathrm{H}, 10.64 ; \mathrm{N}, 1.99$. Found: $\mathrm{C}, 74.63 ; \mathrm{H}$, 11.01; N, 2.17. ${ }^{1} \mathrm{H}$ NMR $\left(400 \mathrm{MHz}, \mathrm{CDCl}_{3}\right): \delta_{\mathrm{H}} 10.72(\mathrm{~s}, 1 \mathrm{H}, \mathrm{N}-\mathrm{CH}-$ $\mathrm{N}), 7.83(\mathrm{~s}, 6 \mathrm{H}, \mathrm{Ar}-H), 7.11(\mathrm{~s}, 1 \mathrm{H}, \mathrm{CH}=\mathrm{CH}), 7.01(\mathrm{~s}, 1 \mathrm{H}, \mathrm{CH}=\mathrm{CH})$, $4.34\left(\mathrm{t}, J=6.7 \mathrm{~Hz}, 2 \mathrm{H}, \mathrm{CH}_{2}-\mathrm{N}\right), 4.23\left(\mathrm{t}, J=6.5 \mathrm{~Hz}, 12 \mathrm{H}, \mathrm{O}-\mathrm{CH}_{2}\right)$, 4.01 (s, 3H, N-CH $\left.H_{3}\right), 1.94$ (br, $\left.14 \mathrm{H}, \mathrm{CH}_{2}\right), 1.62-1.26\left(\mathrm{~m}, 94 \mathrm{H}, \mathrm{CH}_{2}\right)$, $0.88\left(\mathrm{t}, J=6.3 \mathrm{~Hz}, 15 \mathrm{H}, \mathrm{CH}_{3}\right)$. MS (MALDI-TOF): $\mathrm{m} / \mathrm{z}$ calcd for $\left[\mathrm{C}_{88} \mathrm{H}_{149} \mathrm{~N}_{2} \mathrm{O}_{6}(\mathrm{M}-\mathrm{Br})\right]$ : 1330.1; found 1330.1.

Synthesis of 1,3-bis-(6-((3,6,7,10,11pentakis(dodecyloxy)triphenylen-2-yl)oxy)hexyl))-imidazolium bromide, $\left(\mathbf{I m}^{2 \mathrm{Tph}}\right) \mathbf{B r}, \quad 2$. In a first step, 1-(6-((3,6,7,10,11pentakis(dodecyloxy)triphenylen-2-yl)oxy)hexyl)-imidazole was prepared: A solution of imidazole $(17 \mathrm{mg}, 0.22 \mathrm{mmol})$ and sodium hydride $(10.8 \mathrm{mg}, 0.45 \mathrm{mmol})$ in dry THF was stirred under argon until the gas flow $\left(\mathrm{H}_{2}\right)$ stopped. Then, 2-((6-bromohexyl)oxy)3,6,7,10,11-pentakis(dodecyloxy)triphenylene (300 mg, $0.22 \mathrm{mmol}$ ) was added to solution and the mixture was refluxed overnight. The solution was extracted with $\mathrm{CH}_{2} \mathrm{Cl}_{2}$ and water and the organic portions were combined, dried with $\mathrm{MgSO}_{4}$, filtered and the solvent was eliminated by rotary evaporation to obtain a pale yellow residue. The residue was chromatographed in silica with a mixture of $\mathrm{MeOH} / \mathrm{CH}_{2} \mathrm{Cl}_{2}$ as eluent obtaining the desired product as pale yellow solid. Yield: $243 \mathrm{mg}, 84 \%$. Anal. Calcd for $\mathrm{C}_{87} \mathrm{H}_{146} \mathrm{~N}_{2} \mathrm{O}_{6}$ : C, 79.40; $\mathrm{H}$, 11.81; N, 2.13. Found: C, 79.11; H, 11.77; N, $2.47 \%$. ${ }^{1} \mathrm{H}$ NMR (400 $\left.\mathrm{MHz}, \mathrm{CDCl}_{3}\right): \delta_{\mathrm{H}} 7.83(\mathrm{~s}, 6 \mathrm{H}, \operatorname{Ar}-H), 7.57(\mathrm{~s}, 1 \mathrm{H}, \mathrm{N}-\mathrm{C} H-\mathrm{N}), 7.07(\mathrm{~s}$, $1 \mathrm{H}, \mathrm{CH}=\mathrm{CH}), 6.92(\mathrm{~s}, 1 \mathrm{H}, \mathrm{CH}=\mathrm{CH}), 4.22(\mathrm{t}, J=6.9 \mathrm{~Hz}, 12 \mathrm{H}, \mathrm{O}-$ $\left.\mathrm{CH}_{2}\right), 3.98\left(\mathrm{t}, J=6.9 \mathrm{~Hz}, 2 \mathrm{H}, \mathrm{CH}_{2}-\mathrm{N}\right), 1.93\left(\mathrm{br}, 14 \mathrm{H}, \mathrm{CH}_{2}\right), 1.57-1.27$ $\left(\mathrm{m}, 94 \mathrm{H}, \mathrm{CH}_{2}\right), 0.87\left(\mathrm{t}, J=6.5 \mathrm{~Hz}, 15 \mathrm{H}, \mathrm{CH}_{3}\right)$.

In the second step of this preparation a mixture of 2-((6bromohexyl)oxy)-3,6,7,10,11-pentakis(dodecyloxy)triphenylene $\quad(50$ $\mathrm{mg}, \quad 0.035 \mathrm{mmol})$ and 1-(6-((3,6,7,10,11pentakis(dodecyloxy)triphenylen-2-yl)oxy)hexyl)-imidazole $\quad(47.6$ $\mathrm{mg}, 0.035 \mathrm{mmol})$ in acetonitrile was stirred in a microwave at $150{ }^{\circ} \mathrm{C}$ during $1 \mathrm{~h}$. The resulted pale yellow solid was filtered and washed with acetonitrile to obtain the desired product. Yield: $82.4 \mathrm{mg}, 84.0 \%$. Anal. Calcd for $\mathrm{C}_{171} \mathrm{H}_{289} \mathrm{BrN}_{2} \mathrm{O}_{12}$ : C, 77.65; H, 11.01; N, 1.06. Found: $\mathrm{C}, 77.36 ; \mathrm{H}, 11.07 ; \mathrm{N}, 1.26 .{ }^{1} \mathrm{H}$ NMR $\left(400 \mathrm{MHz}, \mathrm{CDCl}_{3}\right): \delta_{\mathrm{H}} 10.91(\mathrm{~s}$, $1 \mathrm{H}, \mathrm{N}-\mathrm{C} H-\mathrm{N}), 7.82(\mathrm{~s}, 12 \mathrm{H}, \mathrm{Ar}-H), 7.02(\mathrm{~s}, 2 \mathrm{H}, \mathrm{CH}=\mathrm{C} H), 4.31(\mathrm{t}, J=$ $\left.6.7 \mathrm{~Hz}, 4 \mathrm{H}, \mathrm{CH}_{2}-\mathrm{N}\right), 4.22\left(\mathrm{t}, J=6.5 \mathrm{~Hz}, 24 \mathrm{H}, \mathrm{O}-\mathrm{CH}_{2}\right), 1.93(\mathrm{br}, 28 \mathrm{H}$, $\left.\mathrm{CH}_{2}\right), 1.62-1.26\left(\mathrm{~m}, 184 \mathrm{H}, \mathrm{CH}_{2}\right), 0.87\left(\mathrm{t}, J=6.3 \mathrm{~Hz}, 30 \mathrm{H}, \mathrm{CH}_{3}\right) . \mathrm{MS}$ (MALDI-TOF): $\mathrm{m} / \mathrm{z}$ calcd for $\left[\mathrm{C}_{171} \mathrm{H}_{289} \mathrm{~N}_{2} \mathrm{O}_{12}(\mathrm{M}-\mathrm{Br})\right]: 2564.2$; found 2564.4.

Synthesis of $\left(\mathrm{Im}^{1 \mathrm{TPh}}\right)\left[\mathrm{AuBr}_{\mathrm{m}} \mathrm{Cl}_{4-\mathrm{m}}\right], 3$ and $\left(\mathrm{Im}^{1 \mathrm{TPh}}\right)_{2}\left[\mathrm{PtBr}_{\mathrm{m}} \mathrm{Cl}_{4-\mathrm{m}}\right] 4$. To a $\mathrm{CH}_{2} \mathrm{Cl}_{2}$ solution of imidazolium salt $1(54.5 \mathrm{mg}, 0.0386 \mathrm{mmol})$ was added a yellow water solution of $\mathrm{HAuCl}_{4} \cdot 3 \mathrm{H}_{2} \mathrm{O}(15.2 \mathrm{mg}, 0.0386$ mmol) or $\mathrm{K}_{2} \mathrm{PtCl}_{4}(8 \mathrm{mg}, 0.0193 \mathrm{mmol})$ and the mixture was stirred during $2 \mathrm{~h}$. When the yellow color disappeared from the water phase, the reaction has finished. The organic layer was separated, washed with water, dried with $\mathrm{MgSO}_{4}$, filtered and the solvent was evaporated. The resultant white solid was the desired product. Yield of 3: $55.6 \mathrm{mg}, 87.6 \%$. Anal. Calcd for $\mathrm{C}_{88} \mathrm{H}_{149} \mathrm{AuCl}_{4} \mathrm{~N}_{2} \mathrm{O}_{6}: \mathrm{C}, 63.29 ; \mathrm{H}$, 8.99; N, 1.68. Found: C, 62.89; H, 9.31; N, 1.43. ${ }^{1} \mathrm{H}$ NMR $(400 \mathrm{MHz}$, $\left.\mathrm{CDCl}_{3}\right): \delta_{\mathrm{H}} 8.90(\mathrm{~s}, 1 \mathrm{H}, \mathrm{N}-\mathrm{CH}-\mathrm{N}), 7.83(\mathrm{~s}, 6 \mathrm{H}, \mathrm{Ar}-H), 7.18(\mathrm{~s}, 1 \mathrm{H}$, $\mathrm{CH}=\mathrm{CH}), 7.06(\mathrm{~s}, 1 \mathrm{H}, \mathrm{CH}=\mathrm{CH}), 4.24\left(\mathrm{br}, 14 \mathrm{H}, \mathrm{O}-\mathrm{CH}_{2}, \mathrm{~N}-\mathrm{CH}_{2}\right), 3.82$ (s, 3H, N-CH $\left.H_{3}\right), 1.94$ (br, 14H, $\mathrm{CH}_{2}$ ), 1.68-1.26 (br, 94H, $\mathrm{CH}_{2}$ ), 0.88 (t, $J=6.3 \mathrm{~Hz}, 15 \mathrm{H}, \mathrm{CH}_{3}$ ). MS (MALDI-TOF): $\mathrm{m} / \mathrm{z}$ calcd for $\left[\mathrm{C}_{88} \mathrm{H}_{149} \mathrm{~N}_{2} \mathrm{O}_{6}\left(\mathrm{M}-\mathrm{AuCl}_{4}\right)\right]: 1330.1$; found $1330.2 ; \mathrm{m} / \mathrm{z}$ calcd for $[\mathrm{M}]$ : 1669.0; 1669.0. Yield of 4: $50.5 \mathrm{mg}, 88.7 \%$. Anal. Calcd for $\mathrm{C}_{176} \mathrm{H}_{298} \mathrm{Cl}_{4} \mathrm{~N}_{4} \mathrm{O}_{12} \mathrm{Pt}: \mathrm{C}, 70.48 ; \mathrm{H}, 10.01 ; \mathrm{N}, 1.87$. Found: $\mathrm{C}, 70.62 ; \mathrm{H}$, $10.12 ; \mathrm{N}, 1.66 .{ }^{1} \mathrm{H}$ NMR $\left(400 \mathrm{MHz}, \mathrm{CDCl}_{3}\right): \delta_{\mathrm{H}} 10.28(\mathrm{~s}, 1 \mathrm{H}, \mathrm{N}-\mathrm{CH}-$ N), $7.83(\mathrm{~s}, 6 \mathrm{H}, \mathrm{Ar}-H), 7.08(\mathrm{~s}, 1 \mathrm{H}, \mathrm{CH}=\mathrm{CH}), 6.97(\mathrm{~s}, 1 \mathrm{H}, \mathrm{CH}=\mathrm{CH})$, 4.40 (br, $\left.2 \mathrm{H}, \mathrm{CH}_{2}-\mathrm{N}\right), 4.22\left(\mathrm{~m}, 12 \mathrm{H}, \mathrm{O}-\mathrm{CH}_{2}\right), 4.04\left(\mathrm{~s}, 3 \mathrm{H}, \mathrm{N}-\mathrm{CH}_{3}\right)$, 
1.93 (br, 14H, $\mathrm{CH}_{2}$ ), 1.57-1.29 (br, 94H, $\mathrm{CH}_{2}$ ), 0.88 (t, $J=6.5 \mathrm{~Hz}$, $\left.15 \mathrm{H}, \mathrm{CH}_{3}\right)$. MS (MALDI-TOF): $\mathrm{m} / \mathrm{z}$ calcd for $\left[\mathrm{C}_{88} \mathrm{H}_{149} \mathrm{~N}_{2} \mathrm{O}_{6}(\mathrm{M}-\right.$ $\left.\mathrm{PtCl}_{4}\right)$ ]: 1330.1 ; found 1330.2 .

Synthesis of $\left[\mathbf{C u B r}\left(\mathbf{N H C}^{1 \mathrm{Tph}}\right)\right], \mathbf{5}$. A mixture of $\mathrm{Cu}_{2} \mathrm{O}(4.6 \mathrm{mg}, 0.032$ $\mathrm{mmol})$ and $1(70 \mathrm{mg}, 0.049 \mathrm{mmol})$ in dry toluene was refluxed under Ar for 24 hours. Then $\mathrm{CH}_{2} \mathrm{Cl}_{2}$ was added, the mixture was filtered over Celite and the filtrate was evaporated. The resultant white residue was the desired product. Yield: $67.3 \mathrm{mg}, 92.3 \%$. Anal. Calcd for $\mathrm{C}_{88} \mathrm{H}_{148} \mathrm{BrCuN}_{2} \mathrm{O}_{6}: \mathrm{C}, 71.73 ; \mathrm{H}, 10.12 ; \mathrm{N}, 1.90$. Found: $\mathrm{C}, 71.41 ; \mathrm{H}$ $10.50 ; \mathrm{N}, 2.12 .{ }^{1} \mathrm{H}$ NMR $\left(400 \mathrm{MHz}, \mathrm{CDCl}_{3}\right): \delta_{\mathrm{H}} 7.83(\mathrm{~s}, 6 \mathrm{H}, \mathrm{Ar}-H)$, $6.17(\mathrm{~d}, J=2.9 \mathrm{~Hz}, 1 \mathrm{H}, \mathrm{CH}=\mathrm{CH}), 6.12(\mathrm{~d}, J=2.9 \mathrm{~Hz}, 1 \mathrm{H}, \mathrm{CH}=\mathrm{CH})$, 4.23 (br, $\left.14 \mathrm{H}, \mathrm{O}-\mathrm{CH}_{2}, \mathrm{CH}_{2}-\mathrm{N}\right), 3.91\left(\mathrm{~s}, 3 \mathrm{H}, \mathrm{N}-\mathrm{CH}_{3}\right), 1.93(\mathrm{br}, 14 \mathrm{H}$, $\left.\mathrm{CH}_{2}\right), 1.55-1.26\left(\mathrm{br}, 94 \mathrm{H}, \mathrm{CH}_{2}\right), 0.88\left(\mathrm{t}, J=6.4 \mathrm{~Hz}, 15 \mathrm{H}, \mathrm{CH}_{3}\right) . \mathrm{MS}$ (MALDI-TOF): $\mathrm{m} / \mathrm{z}$ calcd for $\left[\mathrm{C}_{88} \mathrm{H}_{149} \mathrm{~N}_{2} \mathrm{O}_{6}(\mathrm{M}-\mathrm{CuBr}+\mathrm{H})\right]: 1330.1$; found 1330.1 .

Synthesis of $\left[\mathbf{A g}\left(\mathbf{N H C}^{1 \mathrm{Tph}}\right)_{2}\right]\left[\mathbf{A g B r} \mathbf{r}_{2}\right], \mathbf{6}$. A mixture of $\mathrm{Ag}_{2} \mathrm{O}(4.1 \mathrm{mg}$, $0.017 \mathrm{mmol})$ and $1(50 \mathrm{mg}, 0.035 \mathrm{mmol})$ in $\mathrm{CH}_{2} \mathrm{Cl}_{2}$ was stirred under Ar during $4 \mathrm{~h}$. Then, the suspension was filtered with celite, and the filtrate was dried in the rotary evaporation to obtain a white solid. Yield: $45.8 \mathrm{mg}, 86.2 \%$. Anal. Calcd for $\mathrm{C}_{176} \mathrm{H}_{296} \mathrm{Ag}_{2} \mathrm{Br}_{2} \mathrm{~N}_{4} \mathrm{O}_{12}$ : C, 69.63; H, 9.83; N, 1.85. Found: C, 70.03; H, 9.56; N, 1.68. ${ }^{1} \mathrm{H}$ NMR $\left(500 \mathrm{MHz}, \mathrm{CDCl}_{3}\right): \delta_{\mathrm{H}} 7.83(\mathrm{~s}, 6 \mathrm{H}, \mathrm{Ar}-H), 6.95(\mathrm{~s}, 1 \mathrm{H}, \mathrm{CH}=\mathrm{CH}), 6.88$ $(\mathrm{s}, 1 \mathrm{H}, \mathrm{CH}=\mathrm{CH}), 4.22\left(\mathrm{brm}, 12 \mathrm{H}, \mathrm{O}-\mathrm{CH}_{2}\right), 4.10(\mathrm{t}, J=6.7 \mathrm{~Hz}, 2 \mathrm{H}$, $\left.\mathrm{CH}_{2}-\mathrm{N}\right), 3.77\left(\mathrm{~s}, 3 \mathrm{H}, \mathrm{N}-\mathrm{CH}_{3}\right), 1.94-1.90\left(\mathrm{~m}, 14 \mathrm{H}, \mathrm{CH}_{2}\right), 1.62-1.27$ (m, 94H, $\mathrm{CH}_{2}$ ), 0.87 (t, $J=6.3 \mathrm{~Hz}, 15 \mathrm{H}, \mathrm{CH}_{3}$ ). MS (MALDI-TOF): $\mathrm{m} / \mathrm{z}$ calcd for $\left[\mathrm{C}_{88} \mathrm{H}_{149} \mathrm{~N}_{2} \mathrm{O}_{6}\left(\mathrm{M}-\mathrm{Ag}_{2} \mathrm{Br}_{2} \mathrm{C}_{88} \mathrm{H}_{148} \mathrm{~N}_{2} \mathrm{O}_{6}+\mathrm{H}\right)\right]: 1330.1$; found $1330.1 ; \mathrm{m} / z$ calc. for $\left[\mathrm{AgBr}_{2}\right]: 266.7$; found: 267.4

Synthesis of $\left[\mathbf{A u C l}\left(\mathrm{NHC}^{1 \mathrm{Tph}}\right)\right]$, 7. A mixture of $\mathrm{Ag}_{2} \mathrm{O}(4.7 \mathrm{mg}, 0.02$ mmol) and 1 (58.3 mg, $0.041 \mathrm{mmol}$ ) in $\mathrm{CH}_{2} \mathrm{Cl}_{2}$ was stirred under $\mathrm{Ar}$ during $4 \mathrm{~h}$. Then, AuCl(tht) (13.1 mg, $0.041 \mathrm{mmol})$ was added to a solution and stirred overnight. The suspension was filtered over celite and the solvent was evaporated. The resultant white residue was the desired product. Yield: $56.7 \mathrm{mg}, 88.5 \%$. Anal. Calcd for $\mathrm{C}_{88} \mathrm{H}_{148} \mathrm{AuClN}_{2} \mathrm{O}_{6}: \mathrm{C}, 67.54 ; \mathrm{H}, 9.55 ; \mathrm{N}, 1.79$. Found: $\mathrm{C}, 67.93 ; \mathrm{H}$, 9.63; N, 1.45. ${ }^{1} \mathrm{H}$ NMR $\left(400 \mathrm{MHz}, \mathrm{CDCl}_{3}\right): \delta_{\mathrm{H}} 7.83(\mathrm{~s}, 6 \mathrm{H}, \mathrm{Ar}-H)$, $6.91(\mathrm{~s}, 1 \mathrm{H}, \mathrm{CH}=\mathrm{CH}), 6.83(\mathrm{~s}, 1 \mathrm{H}, \mathrm{CH}=\mathrm{CH}), 4.23-4.18(\mathrm{~m}, 14 \mathrm{H}, \mathrm{O}-$ $\left.\mathrm{CH}_{2}, \mathrm{CH}_{2}-\mathrm{N}\right), 3.78\left(\mathrm{~s}, 3 \mathrm{H}, \mathrm{N}-\mathrm{CH}_{3}\right), 1.94\left(\mathrm{br}, 14 \mathrm{H}, \mathrm{CH} \mathrm{H}_{2}\right), 1.57-1.29$ (m, 94H, $\mathrm{CH}_{2}$ ), 0.88 (t, $J=6.5 \mathrm{~Hz}, 15 \mathrm{H}, \mathrm{CH}_{3}$ ). MS (MALDI-TOF): $\mathrm{m} / \mathrm{z}$ calcd for $\left[\mathrm{C}_{88} \mathrm{H}_{149} \mathrm{~N}_{2} \mathrm{O}_{6}(\mathrm{M}-\mathrm{AuCl}+\mathrm{H})\right]$ : 1330.1 ; found 1330.1 . IR (KBr): $v(\mathrm{Au}-\mathrm{Cl}) 329(\mathrm{~m}) \mathrm{cm}^{-1}$.

Synthesis of $\left[\mathrm{Au}(\mathbf{C} \equiv \mathbf{C P h})\left(\mathbf{N H C}^{1 \mathrm{Tph}}\right)\right], \mathbf{8}$. Same procedure described for 7 but using $[\mathrm{Au}(\mathrm{C} \equiv \mathrm{CPh})]_{\mathrm{n}}$ instead of $\mathrm{AuCl}($ tht $)$. The resultant pale yellow solid was the desired product. Yield: $58.3 \mathrm{mg}, 85.3 \%$. Anal. Calcd for $\mathrm{C}_{96} \mathrm{H}_{153} \mathrm{AuN}_{2} \mathrm{O}_{6}$ : C, 55.25; H, 3.74; N, 3.58. Found: C, 54.86; H, 3.36; N, 3.41. ${ }^{1} \mathrm{H}$ NMR $\left(400 \mathrm{MHz}, \mathrm{CDCl}_{3}\right): \delta_{\mathrm{H}} 7.83(\mathrm{~s}, 6 \mathrm{H}$, $\operatorname{Ar}-H), 7.49(\mathrm{~d}, J=8.31 \mathrm{~Hz}, 2 \mathrm{H}, \operatorname{Ar}-H \mathrm{Ho}), 7.18(\mathrm{t}, J=7.4 \mathrm{~Hz}, 2 \mathrm{H}$ Ar- $H \mathrm{Hm}), 7.15(\mathrm{~d}, J=7.2 \mathrm{~Hz}, 1 \mathrm{H}, \mathrm{Ar}-H \mathrm{Hp}), 6.89(\mathrm{~s}, 1 \mathrm{H}, \mathrm{CH}=\mathrm{CH})$, $6.81(\mathrm{~s}, 1 \mathrm{H}, \mathrm{CH}=\mathrm{CH}), 4.22\left(\mathrm{br}, 14 \mathrm{H}, \mathrm{O}-\mathrm{CH}_{2}, \mathrm{CH}_{2}-\mathrm{N}\right), 3.82(\mathrm{~s}, 3 \mathrm{H}, \mathrm{N}-$ $\left.\mathrm{CH}_{3}\right), 1.93$ (br, $\left.14 \mathrm{H}, \mathrm{CH}_{2}\right), 1.57-1.27\left(\mathrm{~m}, 94 \mathrm{H}, \mathrm{CH}_{2}\right), 0.88$ (t, $J=6.8$ $\mathrm{Hz}, 15 \mathrm{H}, \mathrm{CH}_{3}$ ). MS (MALDI-TOF): $\mathrm{m} / \mathrm{z}$ calcd for $\left[\mathrm{C}_{88} \mathrm{H}_{149} \mathrm{~N}_{2} \mathrm{O}_{6} \mathrm{Au}\right.$ $(\mathrm{M}-\mathrm{CCPh})$ ]: 1526.1; found 1526.2. IR $(\mathrm{KBr}): v(\mathrm{C} \equiv \mathrm{C}) 2115(\mathrm{w}) \mathrm{cm}^{-}$

Synthesis of $\left[\mathrm{PtCl}_{2}\left(\mathrm{NHC}^{1 \mathrm{Tph}}\right)_{2}\right]$, 9. Same procedure described for 7 but using 0.5 eq of $\mathrm{K}_{2} \mathrm{PtCl}_{4}$ instead of 1 eq $\mathrm{AuCl}$ (tht). Isolated as white solid. Yield: $54.3 \mathrm{mg}, 88.3 \%$. Anal. Calcd for $\mathrm{C}_{176} \mathrm{H}_{296} \mathrm{Cl}_{2} \mathrm{~N}_{4} \mathrm{O}_{12} \mathrm{Pt}$ : C, 72.24; H, 10.20; N, 1.91. Found: C, 72.63; H, $10.52 ; \mathrm{N}, 1.55 .{ }^{1} \mathrm{H}$ NMR $\left(400 \mathrm{MHz}, \mathrm{CDCl}_{3}\right): \delta_{\mathrm{H}} 7.83(\mathrm{~s}, 12 \mathrm{H}, \mathrm{Ar}-H)$, $7.10(\mathrm{~s}, 2 \mathrm{H}, \mathrm{CH}=\mathrm{CH}), 6.99(\mathrm{~s}, 2 \mathrm{H}, \mathrm{CH}=\mathrm{CH}), 4.35(\mathrm{t}, J=7.2 \mathrm{~Hz}, 4 \mathrm{H}$, $\left.\mathrm{CH}_{2}-\mathrm{N}\right), 4.22$ (br, 24H, O-CH $\mathrm{CH}_{2}, 4.02\left(\mathrm{~s}, 6 \mathrm{H}, \mathrm{N}-\mathrm{CH}_{3}\right), 1.94$ (br, $28 \mathrm{H}$, $\left.\mathrm{CH}_{2}\right), 1.59-1.27\left(\mathrm{~m}, 188 \mathrm{H}, \mathrm{CH}_{2}\right), 0.88\left(\mathrm{t}, J=6.5 \mathrm{~Hz}, 30 \mathrm{H}, \mathrm{CH}_{3}\right) . \mathrm{MS}$ (MALDI-TOF): $\mathrm{m} / \mathrm{z}$ calcd for $\left[\mathrm{C}_{88} \mathrm{H}_{149} \mathrm{~N}_{2} \mathrm{O}_{6}\left(\mathrm{M}-\mathrm{PtCl}_{2} \mathrm{C}_{88} \mathrm{H}_{148} \mathrm{~N}_{2} \mathrm{O}_{6}\right.\right.$ $+\mathrm{H})$ ]: 1330.1; found 1330.1. IR (KBr): $v(\mathrm{Pt}-\mathrm{Cl}) 368(\mathrm{~m}) \mathrm{cm}^{-1}$.

Synthesis of $\left[\mathbf{C u B r}\left(\mathbf{N H C}^{2 \mathrm{Tph}}\right)\right], \mathbf{1 0}$. A mixture of $\mathrm{Cu}_{2} \mathrm{O}(3.4 \mathrm{mg}$, $0.024 \mathrm{mmol})$ and $2(100 \mathrm{mg}, 0.037 \mathrm{mmol})$ was refluxed in dry toluene under Ar for 24 hours. Then the mixture was filtrated over Celite and the filtrate was evaporated. The white residue was the desired product. Yield: $93.7 \mathrm{mg}, 93.5 \%$. Anal. Calcd for $\mathrm{C}_{171} \mathrm{H}_{288} \mathrm{BrCuN}_{2} \mathrm{O}_{12}$ : C, 75.86; H, 10.72; N, 1.03. Found: C, 75.98; H, 11.09; N, 1.32. ${ }^{1} \mathrm{H}$ NMR $\left(400 \mathrm{MHz}, \mathrm{CDCl}_{3}\right): \delta_{\mathrm{H}} 7.83(\mathrm{~s}, 12 \mathrm{H}, \mathrm{Ar}-H), 6.17(\mathrm{~s}, 2 \mathrm{H}$, $\mathrm{CH}=\mathrm{CH}$ ), $4.22\left(\mathrm{br}, 28 \mathrm{H}, \mathrm{O}-\mathrm{CH}_{2}, \mathrm{CH}_{2}-\mathrm{N}\right), 1.93$ (br, $28 \mathrm{H}, \mathrm{CH}_{2}$ ), 1.57$1.26\left(\mathrm{~m}, 188 \mathrm{H}, \mathrm{CH}_{2}\right), 0.88\left(\mathrm{t}, J=6.4 \mathrm{~Hz}, 30 \mathrm{H}, \mathrm{CH}_{3}\right)$. MS (MALDI-
TOF): $\mathrm{m} / \mathrm{z}$ calcd for $\left[\mathrm{C}_{171} \mathrm{H}_{289} \mathrm{~N}_{2} \mathrm{O}_{12}(\mathrm{M}-\mathrm{CuBr}+\mathrm{H})\right]: 2564.2$; found 2564.4.

Synthesis of $\left[\mathbf{A g}\left(\mathbf{N H C}^{2 \mathrm{Tph}}\right)_{2}\right]\left[\mathbf{A g B r}_{2}\right]$, 11. A mixture of $\mathrm{Ag}_{2} \mathrm{O}(2.95$ $\mathrm{mg}, 0.013 \mathrm{mmol})$ and $2(70 \mathrm{mg}, 0.026 \mathrm{mmol})$ was stirred in dry $\mathrm{CH}_{2} \mathrm{Cl}_{2}$ under Ar for 4 hours. Then the mixture was filtrated over Celite and the filtrate was evaporated. The white residue was the desired product. Yield: $63.5 \mathrm{mg}, 87.4 \%$. Anal. Calcd for $\mathrm{C}_{342} \mathrm{H}_{576} \mathrm{Ag}_{2} \mathrm{Br}_{2} \mathrm{~N}_{4} \mathrm{O}_{24}$ : C, 74.63; H, 10.55; N, 1.02. Found: C, 74.85; $\mathrm{H}, 10.90 ; \mathrm{N}, 1.31 .{ }^{1} \mathrm{H}$ NMR $\left(400 \mathrm{MHz}, \mathrm{CDCl}_{3}\right): \delta_{\mathrm{H}} 7.83(\mathrm{~s}, 24 \mathrm{H}, \mathrm{Ar}-$ $H), 6.91(\mathrm{~s}, 4 \mathrm{H}, \mathrm{CH}=\mathrm{CH}), 4.22\left(\mathrm{br}, 48 \mathrm{H}, \mathrm{O}-\mathrm{CH}_{2}\right), 4.08(\mathrm{t}, J=7.2 \mathrm{~Hz}$, $\left.8 \mathrm{H}, \mathrm{CH}_{2}-\mathrm{N}\right), 1.93-1.91\left(\mathrm{~m}, 56 \mathrm{H}, \mathrm{CH}_{2}\right), 1.56-1.26\left(\mathrm{~m}, 376 \mathrm{H}, \mathrm{CH}_{2}\right)$, $0.88\left(\mathrm{t}, J=6.4 \mathrm{~Hz}, 60 \mathrm{H}, \mathrm{CH}_{3}\right.$ ). MS (MALDI-TOF): $\mathrm{m} / \mathrm{z}$ calcd for [ $\mathrm{AgC}_{342} \mathrm{H}_{576} \mathrm{~N}_{4} \mathrm{O}_{24}\left(\mathrm{M}-\mathrm{AgBr}_{2}\right.$ or $\left.\left.\mathrm{Ag}(\mathrm{NHC})_{2}\right)\right]$ : 5231.3; found 5233.0; $\mathrm{m} / \mathrm{z}$ calcd for $\left[\mathrm{C}_{171} \mathrm{H}_{289} \mathrm{~N}_{2} \mathrm{O}_{12}\left(\mathrm{M}-\mathrm{Ag}_{2} \mathrm{Br}_{2} \mathrm{C}_{171} \mathrm{H}_{289} \mathrm{~N}_{2} \mathrm{O}_{12}+\mathrm{H} /\right.\right.$ cation of 2)]: 2564.2; found 2562.0; calcd for [( $\left.\left.\mathrm{AgBr}_{2}\right)^{-}\right]$: 266.7; found 266.9. Synthesis of $\left[\mathrm{AuCl}\left(\mathrm{NHC}^{2 \mathrm{Tph}}\right)\right]$, 12. A mixture of $\mathrm{Ag}_{2} \mathrm{O}(2.95 \mathrm{mg}$, $0.013 \mathrm{mmol}$ ) and $2(70 \mathrm{mg}, 0.026 \mathrm{mmol})$ in $\mathrm{CH}_{2} \mathrm{Cl}_{2}$ was stirred under Ar during $4 \mathrm{~h}$. Then, AuCl(tht) $(8.2 \mathrm{mg}, 0.026 \mathrm{mmol})$ was added to the solution and stirred overnight. The suspension was filtered over Celite and the solvent was evaporated. The resultant white residue was the desired product. Yield: $67.2 \mathrm{mg}, 91.1 \%$. Anal. Calcd for $\mathrm{C}_{171} \mathrm{H}_{288} \mathrm{AuClN}_{2} \mathrm{O}_{12}$ : C, 73.44; H, 10.38; N, 1.00. Found: C, 73.12; H, $10.57 ; \mathrm{N}, 1.20 .{ }^{1} \mathrm{H}$ NMR $\left(400 \mathrm{MHz}, \mathrm{CDCl}_{3}\right): \delta_{\mathrm{H}} 7.83(\mathrm{~s}, 12 \mathrm{H}, \mathrm{Ar}-H)$, 6.87 (s, 2H, $\mathrm{CH}=\mathrm{CH}), 4.22$ (br, 28H, O- $\mathrm{CH}_{2}, \mathrm{CH}_{2}-\mathrm{N}$ ), 1.93 (br, $28 \mathrm{H}$, $\mathrm{CH}_{2}$ ), $1.56-1.26\left(\mathrm{~m}, 188 \mathrm{H}, \mathrm{CH}_{2}\right), 0.88\left(\mathrm{br}, 30 \mathrm{H}, \mathrm{CH}_{3}\right)$. MS (MALDITOF): $\mathrm{m} / \mathrm{z}$ calcd for $\left[\mathrm{C}_{171} \mathrm{H}_{289} \mathrm{~N}_{2} \mathrm{O}_{12}(\mathrm{M}-\mathrm{AuCl}+\mathrm{H})\right]: 2564.2$; found 2564.3. IR (KBr): $v(\mathrm{Au}-\mathrm{Cl}) 329(\mathrm{~m}) \mathrm{cm}^{-1}$.

Synthesis of $\left[\mathrm{Au}(\mathrm{C} \equiv \mathbf{C P h})\left(\mathrm{NHC}^{2 \mathrm{Tph}}\right)\right], \mathbf{1 3}$. Same procedure described for 12 but using $[\mathrm{Au}(\mathrm{C} \equiv \mathrm{CPh})]_{\mathrm{n}}$ instead of $\mathrm{AuCl}(\mathrm{tht})$. The resultant pale yellow solid was the desired product. Yield: $54.3 \mathrm{mg}, 86.2 \%$. Anal. Calcd for $\mathrm{C}_{179} \mathrm{H}_{293} \mathrm{AuN}_{2} \mathrm{O}_{12}$ : C, 75.11; H, 10.32; N, 0.98. Found: $\mathrm{C}, 74.85 ; \mathrm{H}, 10.13 ; \mathrm{N}, 1.13 .{ }^{1} \mathrm{H}$ NMR $\left(400 \mathrm{MHz}, \mathrm{CDCl}_{3}\right): \delta_{\mathrm{H}} 7.83(\mathrm{~s}$, $12 \mathrm{H}, \operatorname{Ar}-H), 7.47(\mathrm{~d}, J=7.6 \mathrm{~Hz}, 2 \mathrm{H}, \operatorname{Ar}-H), 7.16(\mathrm{t}, J=6.7 \mathrm{~Hz}, 2 \mathrm{H}$, $\operatorname{Ar}-H), 7.11(\mathrm{~d}, J=6.7 \mathrm{~Hz}, 1 \mathrm{H}, \operatorname{Ar}-H), 6.86(\mathrm{~s}, 2 \mathrm{H}, \mathrm{C} H=\mathrm{C} H), 4.22$ (br, $\left.28 \mathrm{H}, \mathrm{O}-\mathrm{CH}_{2}, \mathrm{CH}_{2}-\mathrm{N}\right), 1.93\left(\mathrm{br}, 28 \mathrm{H}, \mathrm{CH}_{2}\right), 1.40-1.25(\mathrm{~m}, 188 \mathrm{H}$, $\mathrm{CH}_{2}$ ), 0.88 (t, $\mathrm{J}=6.7 \mathrm{~Hz}, 30 \mathrm{H}, \mathrm{CH}_{3}$ ). MS (MALDI-TOF): $\mathrm{m} / \mathrm{z}$ calcd for $\left[\mathrm{C}_{171} \mathrm{H}_{289} \mathrm{~N}_{2} \mathrm{O}_{12}(\mathrm{M}-\mathrm{AuCCPh}+\mathrm{H})\right]: 2564.2$; found $2564.2 ; \mathrm{m} / \mathrm{z}$ calcd for $\left[\mathrm{C}_{171} \mathrm{H}_{288} \mathrm{~N}_{2} \mathrm{O}_{12} \mathrm{Au}(\mathrm{M}-\mathrm{CCPh})\right]: 2760.2$; found 2760.2. IR $(\mathrm{KBr}): v(\mathrm{C} \equiv \mathrm{C}) 2117(\mathrm{w}) \mathrm{cm}^{-1}$.

Synthesis of $\left[\mathrm{PtCl}_{2}\left(\mathrm{NHC}^{2 \mathrm{Tph}}\right)_{2}\right]$, 14. Same procedure described for $\mathbf{1 2}$ but using $0.5 \mathrm{eq}$ of $\mathrm{K}_{2} \mathrm{PtCl}_{4}$ instead of 1 eq $\mathrm{AuCl}(\mathrm{tht})$. Isolated as white solid. Yield: $63.7 \mathrm{mg}, 90.8 \%$. Anal. Calcd for $\mathrm{C}_{342} \mathrm{H}_{576} \mathrm{Cl}_{2} \mathrm{~N}_{4} \mathrm{O}_{24} \mathrm{Pt}: \mathrm{C}, 76.12 ; \mathrm{H}, 10.80 ; \mathrm{N}, 1.04$. Found: C, 75.95; H, 11.14; N, 0.94. ${ }^{1} \mathrm{H}$ NMR $\left(400 \mathrm{MHz}, \mathrm{CDCl}_{3}\right): \delta_{\mathrm{H}} 7.83$ (s, 24H, Ar- $H$ ), $6.92(\mathrm{~s}, 4 \mathrm{H}, \mathrm{C} H=\mathrm{CH}), 4.22\left(\mathrm{t}, J=6.4 \mathrm{~Hz}, 48 \mathrm{H}, \mathrm{O}-\mathrm{CH}_{2}\right), 4.08$ (t, $J=$ $\left.7.3 \mathrm{~Hz}, 8 \mathrm{H}, \mathrm{CH}_{2}-\mathrm{N}\right), 1.93$ (br, $\left.56 \mathrm{H}, \mathrm{CH}_{2}\right), 1.56-1.26\left(\mathrm{~m}, 376 \mathrm{H}, \mathrm{CH}_{2}\right)$, 0.88 (br, $60 \mathrm{H}, \quad \mathrm{CH}_{3}$ ). MS (MALDI-TOF): $\mathrm{m} / \mathrm{z}$ calcd for $\left[\mathrm{C}_{171} \mathrm{H}_{289} \mathrm{~N}_{2} \mathrm{O}_{12}\left(\mathrm{M}-\mathrm{PtCl}_{2} \mathrm{C}_{171} \mathrm{H}_{288} \mathrm{~N}_{2} \mathrm{O}_{12}+\mathrm{H}\right)\right]: 2564.2$; found 2564.4 . IR (KBr): $v(\mathrm{Pt}-\mathrm{Cl}) 367(\mathrm{~m}) \mathrm{cm}^{-1}$.

\section{ASSOCIATED CONTENT}

\section{Supporting Information}

${ }^{1} \mathrm{H}$ NMR of compounds, mass spectra of compounds, DSC thermograms not included in the text, indexation tables for imidazolium ligands and carbenes, $\mathrm{X}$-ray diffraction patterns not included in the text, UV-visible data for compounds in dichloromethane solution at $298 \mathrm{~K}$, representative absorption spectrum (absorption spectrum of compound 1), excitation and emission data (nm) in $\mathrm{KBr}$ dispersion and in dichloromethane solution, Emission spectrum of compound $\mathbf{2}$ on heating. The Supporting Information is available free of charge on the ACS Publications website.

\section{AUTHOR INFORMATION}

\section{Corresponding Authors}

* Pablo Espinet: espinet@qi.uva.es

* Silverio Coco: scoco@qi.uva.es 
* Bertrand Donio: bertrand.donnio@ipcms.unistra.fr (SAXS studies)

* Manuel Bardají bardaji@qi.uva.es (luminescence studies) Notes

The authors declare no competing financial interest.

\section{ACKNOWLEDGMENT}

This work was sponsored by the Ministerio de Ciencia e Innovación (Project CTQ2014-52796-P). BD and BH thank CNRS and the University of Strasbourg for support.

\section{REFERENCES}

${ }^{1}$ Bushby R. J.; Kelly S. M., O’Neill M., Liquid crystalline semiconductors: materials, properties and applications. Springer, Dordrecht, Netherlands, 2013.

${ }^{2}$ Kaafarani, B. R. Discotic Liquid Crystals for Opto-Electronic Applications. Chem. Mater. 2011, 23, 378-396.

3 Sergeyev, S.; Pisula, W.; Geerts, Y. H. Discotic liquid crystals: a new generation of organic semiconductors. Chem. Soc. Rev. 2007, 36, $1902-1929$.

${ }^{4}$ Kato, T.; Yasuda, T.; Kamikawa, Y. Self-assembly of functional columnar liquid crystals. Chem. Commun. 2009, 729-739.

${ }^{5}$ Laschat, S.; Baro, A.; Steinke, N.; Giesselmann, F.; Hagele, C.; Scalia, G.; Judele, R.; Kapatsina, E.; Sauer, S.; Schreivogel, A.; Tosoni, M. Discotic Liquid Crystals: From Tailor-Made Synthesis to Plastic Electronics. Angew. Chem. Int. Ed. 2007, 46, 4832-4887.

${ }^{6}$ Hains, A. W.; Liang, Z.; Woodhouse, M. A.; Gregg, B. A. Molecular Semiconductors in Organic Photovoltaic Cells. Chem. Rev. 2010, $110,6689-6735$

${ }^{7}$ Oukachmih, M.; Destruel, P.; Seguy, L.; Ablart, G.; Jolinat, P.; Archambeau, S.; Mabiala, M.; Fouet, S.; Bock, H. New organic discotic materials for photovoltaic conversion. Sol. Energy Mater. Sol. Cells 2005, 85, 535-543.

${ }^{8}$ Wöhrle, T.; Wurzbach, I.; Kirres, J.; Kostidou, A. ; Kapernaum, N.; Litterscheidt, J.; Haenle, J. C.; Staffeld, P.; Baro, A.; Giesselmann, F.; Laschat, S. Discotic liquid crystals. Chem. Rev. 2016, 116, $1139-1241$.

${ }^{9}$ Mori, H.; Itoh, Y.; Nishiura, Y.; Nakamura T.; Shinagawa, Y. Performance of a novel optical compensation film based on negative birefringence of discotic compound for wide-viewing-angle twistednematic liquid-crystal displays. Jpn. J. Appl. Phys. 1997, 36, 143-147.

${ }^{10}$ Kawata, K. Orientation control and fixation of discotic liquid crystal. Chem. Rec. 2002, 2, 59-80.

${ }^{11}$ (a) Borner, R. C.; Bushby, R. J.; Cammidge, A. N.; Jesudason, M. $\mathrm{V}$. The synthesis of triphenylenes-based discotic mesogens new and improved routes. Liq. Cryst. 2006, 33, 1439-1448. (b) Morimoto, K.; Dohi, T.; Kita, Y. Oxidative Trimerization of Catechol to Hexahydroxytriphenylene. Eur. J. Org. Chem. 2013, 9, 1659-1662. (c) Wu, H.; Zhang, C.; Pu, J.; Wang, Y. A. A convenient synthesis method of 3,6-dihydroxy-2,7,10,11-tetrapentyloxytriphenylene from 4,4'-dihydroxybiphenyl with high yield. Liq. Cryst. 2014, 41, 1173-1178. (d) Kong, X.; He, Z.; Gopee, H.; Jing, X.; Cammidge, A. $\mathrm{N}$. Improved synthesis of monohydroxytriphenylenes (MHTs) important precursors to discotic liquid crystal families. Tetrahedron Lett. 2011, 52, 77-79. (e) Stackhouse, P. J.; Hird, M. Influence of acetylene-containing peripheral chains on the mesomorphic properties of triphenylene-based liquid crystals. Liq. Cryst. 2009, 36, 953-965. (f) Cammidge, A. N.; Gopee, H. Synthesis and liquid crystal properties of mixed alkynyl-alkoxy-triphenylenes. Liq. Cryst. 2009, 36, 809-816. (g) Varshney, S. K. Structural isomerism of functionalised triphenylene discotic liquid crystals. Liq. Cryst. 2013, 40, 1477-1486. (h) Mahoney, S. J.; Ahmida, M. M.; Kayal, H.; Fox N.; Shimizu, Y.; Eichhorn, S. H. Synthesis, mesomorphism and electronic properties of nonaflate and cyano-substituted pentyloxy and 3-methylbutyloxy triphenylenes. J. Mater. Chem. 2009, 19, 9221-9232. (i) Zhao, K.-Q.; Jing, M.; An, L.-L.; Du, J.-Q.; Wang, Y.-H.; Hu, P.; Wang, B.-Q.; Monobe, H.; Heinrich, B.; Donnio B. Facile transformation of 1aryltriphenylenes into dibenzo[fg,op $]$ tetracenes by intramolecular Scholl cyclodehydrogenation: synthesis, self-assembly, and charge carrier mobility of large $\pi$-extended discogens. J. Mater. Chem. C 2017, 5, 669-682.

${ }^{12}$ Beltrán, E.; Garzoni, M.; Feringán, B.; Vancheri, A.; Barberá, J.; Serrano, J. L.; Pavan, G. M.; Giménez, R.; Sierra, T. Selforganization of star-shaped columnar liquid crystals with a coaxial nanophase segregation revealed by a combined experimental and simulation approach. Chem. Commun. 2015, 51, 1811-1814.

${ }^{13}$ (a) Hunt, J. J.; Date, R. W.; Timimi, B. A.; Luckhurst G. R.; Bruce, D. W. Toward the Biaxial Nematic Phase of Low Molar Mass Thermotropic Mesogens:- Substantial Molecular Biaxiality in Covalently Linked Rod-Disk Dimers. J. Am. Chem. Soc. 2001, 123, 1011510116. (b) Date R. W.; Bruce D. W. Shape Amphiphiles:- Mixing Rods and Disks in Liquid Crystals. J. Am. Chem. Soc. 2003, 125, 9012-9013. (c) Kouwer P. H. J.; Mehl, G. H. Multiple levels of order in linked disc-rod liquid crystals. Angew. Chem., Int. Ed. 2003, 42, 6015-6018. (d) Jeong, K.; Jing, A. J.; Mansdorf, B.; Graham, M. J.; Yang, D.; Harris F. W.; Cheng, S. Z. D. Biaxial Molecular Arrangement of Rod-Disc Molecule under an Electric Field. Chem. Mater. 2007, 19, 2921-2923. (e) Kouwer P. H. J.; Mehl, G. H. Hierarchical organisation in shape-amphiphilic liquid crystals. J. Mater. Chem. 2009, 19, 1564-1575. (f) Bisoyi, H. K.; Raghunathan V. A.; Kumar, S. A nanophase segregated mesophase morphology in selforganized novel disc-rod oligomesogens. Chem. Commun. 2009, 7003-7005. (g) Tanaka, D.; Ishiguro, H.; Shimizu Y.; Uchida, K. Thermal and photoinduced liquid crystalline phase transitions with a rod-disc alternative change in the molecular shape. J. Mater. Chem. 2012, 22, 25065-25071. (h) Pan, S.; Mu, B.; Zhou, Y.; Li, Q.; Wu, B.; Fang, J.; Chen, D. Competition and compromise between discotic and calamitic mesogens in triphenylene and azobenzene based shapeamphiphilic liquid crystals. RSC Adv., 2016, 6, 49556-49566.

${ }^{14}$ Feringán, B.; Romero, P.; Serrano, J. L.; Folcia, C. L.; Etxebarria, J.; Ortega, J.; Termine, R.; Golemme, A.; Giménez, R.; Sierra, T. HBonded Donor-Acceptor Units Segregated in Coaxial Columnar Assemblies: Toward High Mobility Ambipolar Organic Semiconductors. Segregated Donor-Acceptor Columns in Liquid Crystals That Exhibit Highly Efficient Ambipolar Charge Transport. J. Am. Chem. Soc. 2016, 138, 12511-12518.

${ }^{15}$ Hayashi, H.; Nihashi, W.; Umeyama, T.; Matano, Y.; Seki, S.; Shimizu, Y.; Imahori, H. Segregated Donor-Acceptor Columns in Liquid Crystals That Exhibit Highly Efficient Ambipolar Charge Transport. J. Am. Chem. Soc. 2011, 133, 10736-10739.

${ }^{16}$ Xiao, Y.; Su, X.; Sosa-Vargas, L.; Lacaze, E.; Heinrich, B.; Donnio, B.; Kreher, D.; Mathevet, F.; Attias, A. J. Chemical engineering of donor-acceptor liquid crystalline dyads and triads for the controlled nanostructuration of organic semiconductors. Cryst. Eng. Comm. 2016, 18, 4787-4798.

${ }^{17}$ Zhao, K.-Q.; An, L.-L.; Zhang, X.-B.; Yu, W.-H.; Hu, P.; Wang, B.-Q.; Xu, J.; Zeng, Q.-D.; Monobe, H.; Shimizu, Y.; Heinrich, B.; Donnio, B. Highly Segregated Lamello-Columnar Mesophase Organizations and Fast Charge Carrier Mobility in New Discotic DonorAcceptor Triads. Chem. Eur. J. 2015, 21, 10379-10390.

${ }^{18}$ (a) Zeng, D.; Tahar-Djebbar, I.; Xiao, Y.; Kameche, F.; Kayunkid, N.; Brinkmann, M.; Guillon, D.; Heinrich, B.; Donnio, B.; Ivanov, D. A.; Lacaze, E.; Kreher, D.; Mathevet, F.; Attias, A.-J. Intertwined lamello-columnar coassemblies in liquid-crystalline side-chain $\pi$ conjugated polymers: Toward a new class of nanostructured supramolecular organic semiconductors. Macromolecules 2014, 47, 1715-1731. (b) Xiao, Y.; Zeng, D., Mazur, L. M.; Castiglione, A.; 
Lacaze, E.; Heinrich, B.; Donnio, B.; Kreher, D.; Attias, A.-J.; Ribierre, J.-C.; Mathevet, F. A new class of nanostructured supramolecular organic semiconductors based on intertwined multi-lamellar co-assemblies in $\pi$-conjugated liquid-crystalline side-chain polymers. Polym. J. 2017, 49, 31-39.

${ }^{19}$ Kira, A.; Umeyama, T.; Matano, Y.; Yoshida, K.; Isoda, S.; Park, J. K.; Kim, D.; Imahori, H. Supramolecular Donor-Acceptor Heterojunctions by Vectorial Stepwise Assembly of Porphyrins and Coordination-Bonded Fullerene Arrays for Photocurrent Generation. J. Am. Chem. Soc. 2009, 131, 3198-3200.

${ }^{20}$ Umeyama, T.; Tezuka, N.; Kawashima, F.; Seki, S.; Matano, Y.; Nakao, Y.; Shishido, T.; Nishi, M.; Hirao, K.; Lehtivuori, H.; Tkachencko, N. V.; Lemmetyinen, H.; Imahori, H. Carbon Nanotube Wiring of Donor-Acceptor Nanograins by Self-Assembly and Efficient Charge Transport. Angew. Chem., Int. Ed. 2011, 50, 4615-4619.

${ }^{21}$ (a) Kumar, S. Self-organization of disc-like molecules: chemical aspects. Chem. Soc. Rev. 2006, 35, 83-109. (b) Kumar, S. Recent developments in the chemistry of triphenylene-based discotic liquid crystals. Liq. Cryst. 2004, 31, 1037-1059. (c) Kumar, S.; Setia, S.; Avinash, B. S.; Kumar, S. Triphenylene-based discotic liquid crystals: recent advances. Liq.Cryst. 2013, 40, 1769-1816.

${ }^{22}$ Kumar, S. Triphenylene-based discotic liquid crystal dimers, oligomers and polymers. Liq. Cryst. 2005, 32, 1089-1113.

${ }^{23}$ Kumar, S.; Varshney, S. K. A new form of discotic metallomesogens: the synthesis of metal-bridged triphenylene discotic dimers. Liq. Cryst. 2001, 28, 161-163.

24 Schulte, J. L.; Laschat, S.; Schulte-Ladbeck, R.; von Arnim, V.; Schneider, A.; Finkelmann, H. Preparation of $\left(\eta^{6}-\right.$ alkoxytriphenylene)tricarbonyl chromium(0) complexes: Mesomorphic properties of a disk-shaped chromium-arene complex. J. Organomet. Chem. 1998, 552, 171-176.

${ }^{25}$ Cammidge, A. N.; Gopee. H. Macrodiscotic triphenylenophthalocyanines. Chem. Commun. 2002, 966-967.

${ }^{26}$ Mohr, B.; Wegner, G.; Ohta, K. Synthesis of triphenylene-based porphyrazinato metal(II) complexes which display discotic columnar mesomorphism. J. Chem. Soc., Chem. Commun. 1995, 995-996.

${ }^{27}$ Yang, F.; Bai, X.; Guo, H.; Li, C. Ion complexation-induced mesomorphic conversion between two columnar phases of novel symmetrical triads of triphenylene-calix[4]arene-triphenylenes. Tetrahedron Lett. 2013, 54, 409-413.

${ }^{28}$ Shi, J.; Wang, Y.; Xiao, M.; Zhong, P.; Liu, Y.; Tan, H.; Zhu, M.; $\mathrm{Zhu}, \mathrm{W}$. Luminescent metallomesogens based on platinum complex containing triphenylene unit. Tetrahedron 2015, 71, 463-469.

${ }^{29}$ Chico, R.; Domínguez, C.; Donnio, B.; Heinrich, B.; Coco, S.; Espinet, P. Isocyano-Triphenylene Complexes of Gold, Copper, Silver, and Platinum. Coordination Features and Mesomorphic Behavior. Cryst. Growth Des. 2016, 16, 6984-6991.

${ }^{30}$ Tritto, E.; Chico, R.; Sanz-Enguita, G.; Folcia, C. L.; Ortega, J.; Coco, S.; Espinet, P. Alignment of Palladium Complexes into Columnar Liquid Crystals Driven by Peripheral Triphenylene Substituents. Inorg. Chem. 2014, 53, 3449-3455.

${ }^{31}$ Tritto, E.; Chico, R.; Ortega, J.; Folcia, C. L.; Etxebarria, J.; Coco, $\mathrm{S}$; Espinet, P. Synergistic $\pi-\pi$ and $\mathrm{Pt}-\mathrm{Pt}$ interactions in luminescent hybrid inorganic/organic dual columnar liquid crystals. J. Mater. Chem. C 2015, 3, 9385-9392.

${ }^{32}$ Chico, R.; de Domingo, E.; Domínguez, C.; Donnio, B.; Heinrich, B.; Termine, R.; Golemme, A.; Coco, S.; Espinet, P. High OneDimensional Charge Mobility in Semiconducting Columnar Mesophases of Isocyano-Triphenylene Metal Complexes. Chem. Mater. 2017, 29, 7587-7595.

${ }^{33}$ (a) Guo, H.; Lin, L.; Qiu, J.; Yang, F. Phenylacrylonitrile-bridging triphenylene dimers: the columnar liquid crystals with high fluorescence in both solid state and solution, RSC Adv., 2017, 7, 5331653321. (b) Fang, X.; Guo, H.; Lin, J.; Yang, F. Synthesis, mesomorphism and fluorescence of triphenylene-Bodipy dyads, Tetrahedron Lett. 2016, 57, 4939-4943.
${ }^{34}$ (a) Ray, S.; Mohan, R.; Singh, J. K.; Samantaray, M. K.; Shaikh, M. M.; Panda, D.; Ghosh, P. Anticancer and Antimicrobial Metallopharmaceutical Agents Based on Palladium, Gold, and Silver NHeterocyclic Carbene Complexes. J. Am. Chem. Soc. 2007, 129, 15042-15053. (b) Niu, W.; Chen; X.; Tan, W.; Veige, A. S. NHeterocyclic Carbene-Gold(I) Complexes Conjugated to a LeukemiaSpecific DNA Aptamer for Targeted Drug Delivery. Angew. Chem. Int. Ed. 2016, 55, 8889-8893. (c) Mercsa, L.; Albrecht, M. Beyond catalysis: $N$-heterocyclic carbene complexes as components for medicinal, luminescent, and functional materials applications. Chem. Soc. Rev. 2010, 39, 1903-1912. (d) Lazreg, F.; Cazin, C. S. J. N-Heterocyclic Carbenes: Effective Tools for Organometallic Synthesis. Chapter 7: Medical Applications of NHC-Gold and-Copper Complexes (Ed. S. P. Nolan) Wiley, 2014. (e) Flanigan, D. M.; Romanov-Michailidis, F.; White, N. A.; Rovis, T. Organocatalytic Reactions Enabled by N-Heterocyclic Carbenes. Chem. Rev. 2015, 115, 9307-9387.

35 Díez-Gonzalez, S.; Marion, N.; Nolan S. P. N-Heterocyclic Carbenes in Late Transition Metal Catalysis. Chem. Rev. 2009, 109, 3612-3676.

${ }^{36}$ Goossens, K.; Lava, K.; Bielawski, C. W.; Binnemans, K. Ionic Liquid Crystals: Versatile Materials. Chem. Rev. 2016, 116 , 4643-4807.

${ }^{37}$ (a) Pal, S. K.; Kumar, S. Microwave-assisted synthesis of novel imidazolium-based ionic liquid crystalline dimers. Tetrahedron Lett. 2006, 47, 8993-8997, (b) Kumar. S.; Kumar Gupta, S. The first examples of discotic liquid crystalline gemini surfactants. Tetrahedron Lett. 2010, 51, 5459-5462, (c) Kumar, S.; Pal, S. K.; Synthesis and characterization of novel imidazolium-based ionic discotic liquid crystals with a triphenylene moiety. Tetrahedron Lett. 2005, 46 , 2607-2610. d) Cui, L., Zhu, L. Ionic interaction induced novel ordered columnar mesophases in asymmetric discotic triphenylene salts. Liq. Cryst. 2006, 33, 811-818.

38 Appelhans, L. N.; Zuccaccia, D.; Kovacevic, A.; Chianese, A. R.; Miecznikowski, J. R.; Macchioni, A.; Clot, E.; Eisenstein, O.; Crabtree, R. H. An Anion-Dependent Switch in Selectivity Results from a Change of $\mathrm{C}-\mathrm{H}$ Activation Mechanism in the Reaction of an Imidazolium Salt with $\mathrm{IrH}_{5}\left(\mathrm{PPh}_{3}\right)_{2}$. J. Am. Chem. Soc. 2005, 127, 16299-16311.

${ }^{39}$ Cha, S.; Kim, D. Anion exchange in ionic liquid mixtures. Phys. Chem. Chem. Phys. 2015, 17, 29786-23792.

${ }^{40}$ See for example Loupy, A.; Tchoubar, B. Salt effects in organic and organometallic chemistry. VCH, Weinheim, 1992.

${ }^{41}$ (a) Liz-Marzán, L. Gold nanoparticle research before and after the Brust-Schiffrin method. Chem. Commun. 2013, 49, 16-18. (b) Booth, S. G.; Uehara, A.; Chang, S.-Y.; La Fontaine, C.; Fujii, T.; Okamoto, Y.; Imai, T.; Schroeder, S. L. M.; Dryfe, R. A. W. The significance of bromide in the Brust-Schiffrin synthesis of thiol protected gold nanoparticles. Chem. Sci., 2017, 8, 7954-7962. (c) Perala, S. R. K.; Kumar, S. On the Mechanism of Metal Nanoparticle Synthesis in the Brust-Schiffrin Method. Langmuir 2013, 29, 9863-9873.

${ }^{42}$ (a) Collado, A.; Gómez-Suárez, A.; Martin, A. R.; Slawin, A. M. Z.; Nolan, S. P. Straightforward synthesis of $[\mathrm{Au}(\mathrm{NHC}) \mathrm{X}](\mathrm{NHC}=N-$ heterocyclic carbene, $\mathrm{X}=\mathrm{Cl}, \mathrm{Br}, \mathrm{I})$ complexes. Chem. Commun. 2013, 49, 5541-5543. (b) Johnson, A.; Gimeno, M. C. An efficient and sustainable synthesis of NHC gold complexes. Chem. Commun. 2016, 52, 9664-9667.

${ }^{43}$ a) Hsu, T. H. T.; Naidu, J. J.; Yang, B.-J.; Jang, M.-Y.; Lin, I. J. B. Self-Assembly of Silver(I) and Gold(I) N-Heterocyclic Carbene Complexes in Solid State, Mesophase, and Solution. Inorg. Chem. 2012, 51, 98-108. (b) Wang, H. M. J.; Lin, I. J. B. Facile Synthesis of Silver(I)-Carbene Complexes. Useful Carbene Transfer Agents. Organometallics, 1998, 17, 972-975. c) Pana, A., Ilis, M., Micutz, M., Dumitrasçu, F.; Pasuk, I.; Cîrcu, V. Liquid crystals based on silver carbene complexes derived from dimeric bis(imidazolium) bromide salts. RSC Adv. 2014, 4, 59491-59497. 
44 (a) Jahnkea, M. C.; Paleyb, J.; Hupkaa, F.; Weiganda, J. J.; Ekkehardt Hahn, F. Silver and Gold Complexes with Benzimidazolin2-ylidene Ligands. Naturforsch. 2009, 64b, 1458-1462. (b) Huang, R. T. W.; Wang, W. C.; Yang, R. Y.; Lu, J. T.; Lin, I. J. B. Liquid crystals of gold(I) N-heterocyclic complexes. Dalton Trans. 2009, 7121-7131. (c) Han, Z.; Bates, J.I.; Strehl, D.; Patrick, B. O.; Gates, D. P. Homo- and Heteropolynuclear Complexes Containing Bidentate Bridging 4-Phosphino-N-Heterocyclic Carbene Ligands. Inorg. Chem. 2016, 55, 5071-5078.

(a) Nakamoto, K. Infrared and Raman Spectra of Inorganic and Coordination Compounds. Part B.; $5^{\text {th }}$ edition; John Wiley and Sons; New York, 1997; pp 10-11. (b) Newman, C. P.; Deeth, R. J.; Clarkson, G. J.; Rourke, J. P. Synthesis of Mixed NHC/L Platinum(II) Complexes:- Restricted Rotation of the NHC Group. Organometallics 2007, 26, 6225-6233. (c) Hering, F.; Radius, U. From NHC to Imidazolyl Ligand: Synthesis of Platinum and Palladium Complexes $\mathrm{d}^{10}$ $\left[\mathrm{M}(\mathrm{NHC})_{2}\right](\mathrm{M}=\mathrm{Pd}, \mathrm{Pt})$ of the NHC 1,3-Diisopropylimidazolin-2ylidene. Organometallics, 2015, 34, 3236-3245, (d) Muenzner, J. K.; Rehm, T. S.; Biersack, B.; Casini, A.; de Graaf, I. A. M.; Worawutputtapong, P.; Noor, A.; Kempe, R.; Brabec, V.; Kasparkova, J.; Schobert, R. Adjusting the DNA Interaction and Anticancer Activity of $\mathrm{Pt}(\mathrm{II}) \mathrm{N}$-Heterocyclic Carbene Complexes by Steric
Shielding of the Trans Leaving Group. J. Med. Chem. 2015, 58, 6283-6292.

${ }^{46}$ Donnio, B. Heinrich, B. Allouchi, H. Kain, J. Diele, S. Guillon, D. Bruce, D. W. J. Am. Chem. Soc. 2004, 126, 15258-15268. (A generalized model for the molecular arrangement in the columnar mesophases of polycatenar mesogens. Crystal and molecular structure of two hexacatenar mesogens).

${ }^{47}$ Guichemerre, M.; Chambaud, G.; Stoll, H. Electronic structure and spectroscopy of monohalides of metals of group I-B. Chem. Phys. 2002, 280, 71-102.

${ }^{48}$ Huheey, J. E. Inorganic Chemistry. Principles of Structure and Reactivity; Harper \& Row: London, 1975; pp 160-167.

${ }^{49}$ Cordero, B.; Gómez, V.; Platero-Prats, A. E.; Revés, M.; Echeverría, J.; Cremades, E.; Barragán, F.; Alvarez, S. Covalent radii revisited. Dalton Trans. 2008 2832-2838.

${ }^{50}$ Markovitsi, D.; Germain, A.; Millié, P.; Lécuyer, P.; Gallos, L. K.; Argyrakis, P.; Bengs, H.; Ringsdorf, H. Triphenylene Columnar Liquid Crystals: Excited States and Energy Transfer. J. Phys. Chem., 1995, 99, 1005-1017.

${ }^{51}$ Usón, R.; Laguna, A.; Laguna, M. (Tetrahydrothiophene)gold(I) or gold(III) complexes. Inorg. Synth. 1989, 26, 85-91.

52 Alejos, P.; Coco, S.; Espinet, P. Liquid crystals based on alkynylgold(I) isonitrile complexes. New J. Chem. 1995, 19, 799-805.

\section{Insert Table of Contents artwork here}

Spontaneous segregation taking place in triphenylene-imidazolium salts and in their NHC metal complexes, into organic columnar zones and metal containing or ionic columnar zones, produces columnar discotic ionic liquids and metallomesogens with columns of different nature.

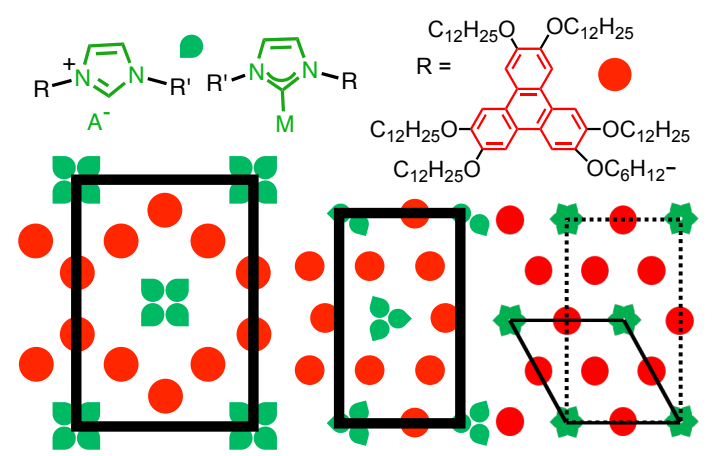

